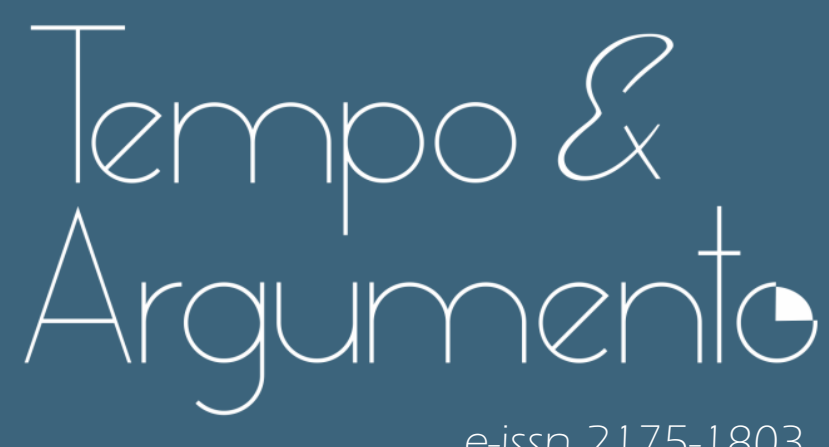

e-issn 2175-1803

\title{
A trajetória das divisões pesadas da URSS e Rússia e dos EUA ao início e ao final da Guerra Fria
}

- Domicio Proença Junior

Doutor em Engenharia de Produção pela Universidade Federal do Rio de Janeiro (UFRJ). Ordem do Mérito da Defesa, República Federativa do Brasil.

Professor da Universidade Federal do Rio de Janeiro (UFRJ).

Rio de Janeiro, RJ - BRASIL lattes.cnpq.br/5299835944080361

domicio.proenca.jr@gmail.com

(iD) orcid.org/0000-0003-1051-7866

- Eugenio Diniz

Doutor em Engenharia de Produção pela Universidade Federal do Rio de Janeiro (UFRJ). Professor da Pontifícia Universidade Católica de Minas

Gerais (PUC-Minas).

Belo Horizonte, MG - BRASIL

lattes.cnpq.br/5414283625973469

eudiniz@pucminas.br

(iD) orcid.org/0000-000 1-7059-0243

- Marcus A. Lessa

Doutorando em Engenharia de Produção na Universidade Federal do Rio de Janeiro (UFRJ). Professor da Universidade Federal do Rio de Janeiro (UFRJ).

Rio de Janeiro, RJ - BRASIL

lattes.cnpq.br/2093672905030990

marcus.lessa@gmail.com

(iD) orcid.org/0000-0001-7844-6182

Para citar este artigo:

PROENCA JUNIOR, Domicio; DINIZ, Eugenio; LESSA, Marcus A. A trajetória das divisões pesadas da URSS e Rússia e dos EUA ao início e ao final da Guerra Fria.

Tempo e Argumento, Florianópolis, v. 13, n. 32, e0 106, jan./abr. 2021.

doi http://dx.doi.org/10.5965/2175180313322021e0106

Recebido: 27/10/2020

Aprovado: $11 / 03 / 2021$ 


\title{
A trajetória das divisões pesadas da URSS e Rússia e dos EUA ao início e ao final da Guerra Fria
}

\begin{abstract}
Resumo
Este artigo apresenta e discute o trajeto que levou os desenhos organizacionais das divisões pesadas da URSS e dos EUA ao início e ao final da Guerra Fria. Para tanto, explica as armas combinadas modernas centradas no tanque e o papel central do escalão de comando divisão (10.000-20.000 combatentes) para a disponibilização dos diferentes tipos de tropas necessários para que se possa têlas quando necessário. Apresenta então os corpos de tanques e mecanizados da URSS, e a divisão blindada dos EUA em 1945, delineando como se chegou às divisões de rifles motorizados e de tanques da URSS e às divisões blindadas e mecanizadas dos EUA tomando c. 1985 como proxy para 1991 em função da turbulência do final da Guerra Fria. A conclusão afirma a continuidade e prevalência do enquadramento de disponibilização de armas combinadas modernas centradas no tanque na divisão como consideração principal no desenho organizacional de forças terrestres até o presente.
\end{abstract}

Palavras-chave: Estudos Estratégicos. Forcas Armadas. Projeto de Força. Tecnologia. Desenho Organizacional.

\section{The trajectory of the heavy divisions of USSR/Russia and of the USA at the start and end of the Cold War}

\begin{abstract}
This article presents and discusses the path that led to the organizational designs of the heavy division of the USSR and the USA at the start and at the end of the Cold War. It explains modern combined arms centred on the tank, and the central role of the army division (10,000-20,000 combatants) for the provision of the different types of troops required to have them when necessary. It then addresses the tank and mechanized corps of the USSR and the armored division in 1945, outlining how these led to the motor rifle and tank divisions of the USSR and the armored and mechanized divisions of the USA c. 1985, as proxy for 1991 to account to the turbulence at the end of the Cold War. It argues in conclusion for the continuity and prevalence of the issue of providing for combined arms centred on the tank in the division as the prime concern for the organizational design of ground forces to the present..
\end{abstract}

Keywords: Strategic Studies. Armed Forces. Force Design. Technology. Organizational Design. 


\section{Introdução}

Nos anos finais da Primeira Guerra Mundial, a motorização e a introdução do tanque como um novo armamento reconfiguraram as possibilidades no combate terrestre. Seu efeito e potencial impuseram um repensar sobre como compor as armas combatentes (infantaria, cavalaria, artilharia) e mais ainda sobre como articulá-las no combate.

Enquanto concepção, motorização e tanques expressavam um novo e mais avançado estado da arte bélico que em pouco tempo passou a ser partilhado por todos os países. Por isso, e diante das vantagens que prometiam, dali em diante todo projeto de força procuraria deliberadamente dar conta de organizar, equipar, treinar e manter forças combatentes capazes de dispor e fazer uso da motorização e dos tanques.

Entretanto, a adoção de um projeto de força diante desse estado da arte partilhado estava sujeita a fatores contextuais e situados próprios de cada país. Havia questões políticas: escolher quais forças ter e por que, para lutar contra qual oponente? Também havia os limites materiais e humanos em cada um.

Embora as principais potências soubessem das vantagens conferidas por armas combinadas motorizadas que dispusessem de tanques e, justamente por isso, ambicionavam tê-las, isso não era tão simples assim. Na verdade, restrições de contexto e situação podiam levar a resultados muito distantes do que se tinha ambicionado à luz do estado da arte. E, quanto mais distantes os resultados, maiores eram as chances de nem se ter e nem se poder usar armas combinadas, fosse pela falta de armamentos, veículos motorizados ou tanques adequados, fosse por não saber compô-los em organizações capazes de conduzir e sustentar a luta.

Isso porque estar no estado da arte exige mais que ter ou ser capaz de produzir determinados armamentos.

Para ter e poder usar armas combinadas aproveitando as vantagens que elas podem conferir é preciso dispor de tropas com competências diversas, inclusive a de saber agir coordenadamente, e de uma ampla variedade de equipamentos para lidar com diferentes situações. Mais ainda, é preciso dispor 
de quantidades suficientes de pessoal e equipamentos, seja para desdobrar a força no espaço, seja para fazê-la perdurar no tempo. Isso quer dizer que o estado da arte bélico compreende uma dimensão tecnológica e outra organizacional, que busca dar conta de questões de escopo (quais competências para combater, planejar e coordenar, quais variedades de equipamentos) e de escala (quais quantidades de pessoal e equipamentos). A dimensão organizacional é central porque é a partir da solução adequada dessas questões de escopo e escala que se pode ter uma força capaz de combater usando armas combinadas.

Essa foi a questão que se pôs diante das duas superpotências da Guerra Fria, a União das Repúblicas Socialistas Soviéticas (URSS) e os Estados Unidos da América (EUA); como cada uma lidou com ela pode ser observado comparando os trajetos dos desenhos das suas respectivas forças motorizadas e de tanques. Com isso, pode-se apreciar o processo histórico de influências mútuas entre a promessa do estado da arte partilhado e escolhas políticas e restrições materiais de cada uma, e como isso veio a produzir uma dada organização das suas forças terrestres. Mas pode-se ir além, ajuizando os esforços efetivados nas últimas três décadas para se romper com o estado da arte no que se refere à sua dimensão organizacional, mais especificamente o tamanho ótimo da unidade combatente terrestre. Esse esforço pretendia (e pretende) ver a divisão, com 10 a 20 mil combatentes, substituída pela brigada, com 3 a 5 mil combatentes, sem perda da capacidade de combater com armas combinadas diante de tal redução.

Assim, este artigo busca contribuir, considerada a história do tempo presente, para um entendimento do processo de projeto de força como a conjunção de um determinado estado da arte bélico e da realidade logística socialmente situada em cada país, preenchendo lacunas que permitiriam melhor explicar os desenhos de forças terrestres, no rumo da agenda de pesquisa proposta por Glantz (2010, p. 29), para “apoiar, clarificar, desenvolver, criticar ... [o panorama do desenvolvimento contextualizado dos exércitos soviético e russo]".

Para tanto, apresentar-se-á de início a perspectiva metodológica das armas combinadas (Seção 1.1), para explicar seus principais conceitos e como eles podem ser articulados para que se compreendam os desafios do desenho 
de forças combatentes terrestres, sobretudo no que concerne às interrelações entre capacidades combatentes (escopo) e a disponibilidade de quantidades suficientes de pessoal e equipamentos para sustentá-las no espaço e no tempo (escala). Essa discussão termina identificando, no estado da arte, a centralidade da divisão como ponto ótimo de composição de tais relações. Em seguida, analisar-se-ão os desenhos das divisões pesadas da URSS e dos EUA, comparando-os em dois momentos: no final da Segunda Guerra Mundial (1945) (Seção 2) e no auge da Guerra Fria, na Frente Central da Europa (c. 1985) (Seção 3) o que permitirá observar que, a despeito de terem se orientado por diferentes decisões políticas e sido limitadas por diferentes restrições materiais e humanas, ambas as superpotências procuraram manter o enquadramento divisional como foco de seus projetos de força terrestre. Na Conclusão (Seção 4), após uma breve recapitulação em que são comparados os desenhos soviético e estadunidense, serão apresentados sinteticamente os problemas enfrentados pela Rússia para reconfigurar suas forças terrestres de forma a retomar a divisão após um período em que teve de tentar fazê-lo em torno da brigada.

Com isso, se poderá demonstrar a continuidade da divisão como desenho organizacional prevalente em forças que buscam combater com armas combinadas. Mesmo assim, compreende-se como a brigada se apresentou como uma alternativa sedutora: ela basta para missões de contra-insurgência, de paz ou mesmo de ocupação de território. Todavia, os seus limites começam a ser revelados quando é preciso combater um oponente capaz de prosseguir na luta por muitos dias ou semanas.

E, no entanto, é em torno de brigadas que se propôs conceber e conduzir projetos de força terrestre nas últimas três décadas, o que talvez só tenha sido politicamente aceitável diante da falta de combates que pusessem tais forças realmente à prova. Assim, tem-se uma aplicação presente do conteúdo do artigo no sentido de avivar e consolidar o entendimento de que o auge do estado da arte, para poder combater com armas combinadas, continua sendo o enquadramento divisional, realidade que não se alterou nem mesmo diante da promessa tecnológica conferida por armamentos modernos e pela digitalização. 


\subsection{Armas Combinadas}

Para compreender o desenho de forças terrestres no período da Guerra Fria é necessário adotar a perspectiva metodológica das armas combinadas aplicada ao projeto de força, ou seja, o desenho deliberado da composição de material e pessoal pelo qual se concebem e se preparam forças combatentes (DUPUY, 1990; EVANS, 2003; HOUSE, 2002; JORDAN et al., 2016).

Em sua expressão mais simples, dar conta de um projeto de força terrestre de forma bem-sucedida significa ter a força que se julga adequada quando necessário e ser capaz de sustentá-la em ação pelo tempo que se fizer necessário. Esse problema, enfrentado pela URSS e os EUA em diversos momentos, também se faz relevante para qualquer outra sociedade soberana: saber quais forças se pode ter e o que se pode fazer com as forças que se têm. A perspectiva das armas combinadas permite comparar diretamente diferentes projetos de força em função dos seus resultados combatentes, aproveitando o que se pode aprender com isso para propor redesenhos ou mudanças de conduta diante do que é dado pelo estado da arte bélico e das decisões políticas e restrições humanas e materiais (O'HANLON, 2009; TUCK, 2014).

Ela se baseia inicialmente no reconhecimento de que diferentes composições de pessoal, armamento e práticas levam a capacidades combatentes diferenciadas. Daí decorre que o arranjo ótimo para enfrentar uma dada composição sempre envolverá uma disposição ótima de tropas capazes de realizar determinadas práticas no tempo e no espaço. Tropas que manejam armamentos ou sistemas de armamentos contra tropas oponentes são ditas armas combatentes: infantaria, que combate a pé (mesmo que se desloque ou use armamentos em veículos); cavalaria, que combate montada em veículos de qualquer tipo; e artilharia, que combate à distância. Tratam-se por extensão também como armas, mas armas de suporte ou de apoio, os vários tipos de tropas cujo papel não é o manejo de armamentos em combate, mas que facilitam ou multiplicam o agir das armas combatentes: sistemas de sensoriamento, de sinais (comunicação), de apoio ao movimento (engenharia) ou de preservação da capacidade de combater (suprimento, manutenção, medicina). 
Existem dois principais desafios no desenho de forças combatentes terrestres. O primeiro diz respeito às competências das diferentes tropas, de armas distintas, que devem ser formadas e estar à disposição, e à variedade de armamentos e equipamentos necessários, ou seja, o problema de escopo das capacidades e dos equipamentos que se deseja ter na força. O segundo diz respeito ao dimensionamento das partes da força em termos do seu número, ou seja, o problema de escala suficiente para dispor da força no espaço e ao longo do tempo.

Em relação ao escopo, o foco da questão é realmente ter competência suficiente para obter as vantagens combatentes de armas combinadas: para se pôr no auge do estado da arte. Entretanto, existem formas alternativas de combater que também podem produzir vantagem, sobretudo se não se estiver enfrentando oponentes que fazem uso de armas combinadas.

Quando se considera o combate entre tropas da mesma arma, com capacidades combatentes análogas, a vantagem que se pode obter decorre de número, posição e do desempenho relativo de uma e da outra. Pode-se ter ainda tropas de uma arma combatendo tropas de outra arma, e aí busca-se vantagem não apenas no número, posição e desempenho relativo, mas principalmente nas assimetrias de capacidades combatentes. Nesses casos, trata-se de armas isoladas: cada tropa faz aquilo que é mais afeito às suas capacidades combatentes. Por exemplo, a infantaria enfrentando tanques procurará por emboscadas em que as vantagens de mobilidade, proteção e poder de fogo dos tanques sejam embaraçadas pelo uso do terreno e pela surpresa. Analogamente, tanques enfrentando infantaria buscam espaços de tiro e manobra de maneira a explorar a geometria relativa contra as posições e de forma a minimizar o uso do terreno pela infantaria.

Pode-se combater usando mais de um tipo de arma, empregando sucessivamente diferentes armas contra o oponente. Como cada arma exige um arranjo ótimo para que se possa utilizá-la com vantagem, o uso sucessivo de diferentes armas obriga o oponente a ter que modificar seus arranjos para lidar ora com uma, ora com outra, impondo-lhe assim uma desvantagem. Nesse caso, trata-se de armas alternadas, em que se busca vantagem pela exploração das 
desvantagens que o oponente passa a ter em função do que tiver feito para lidar com a arma anterior e durante a passagem de um arranjo para outro. Por exemplo, a infantaria disposta para emboscar tanques está mal posicionada para enfrentar outra infantaria ou para lidar com artilharia; os tanques que tiveram que buscar posições de tiro e manobra para enfrentar a infantaria estão mal postos para lidar com outros tanques ou com artilharia, e assim por diante.

É possível também empregar associadamente diferentes armas contra o oponente. Quando se tem a posse de diferentes armas capazes de agir cooperativamente, é possível obrigar o oponente a adotar um arranjo que não seja ótimo para lidar com nenhuma delas isoladamente, mesmo que seja capaz de lidar com todas elas em alguma medida. Como resultado, o oponente luta em desvantagem. Neste caso, trata-se de armas apoiadas, em que se busca explorar as capacidades combatentes de armas diferentes para que o arranjo do oponente deixe a desejar. Por exemplo, a infantaria pode ser apoiada pela manobra ou poder de fogo dos tanques ao redor do seu posicionamento e contar com fogos de artilharia para enfraquecer o oponente com barragens preparatórias, ou embaraçar os movimentos do oponente enquanto estiver rearranjando suas forças.

Mas o auge do estado da arte é quando se tem diferentes armas capazes de agir de maneira tão concentrada no espaço e unificada no tempo que o oponente não tem como adotar um arranjo que possa dar conta desse conjunto. De fato, qualquer arranjo que adote para dar conta de uma das armas o exporá às vantagens das demais. Nesse caso, trata-se de armas combinadas, em que se busca maximizar as diferentes características de diferentes armas diante de qualquer que seja o arranjo do oponente. Em armas combinadas, a infantaria segue lado a lado com os tanques dispondo de uma artilharia que é capaz de responder a chamados diferenciados e específicos durante o próprio desenrolar do combate.

Reconhece-se a dificuldade de dispor e sustentar formaturas combatentes capazes de prover e fazer uso de armas combinadas de maneira fluente. Não é fácil nem simples ter tropas competentes tanto no que é relevante para as condutas combatentes da sua própria arma quanto para atuar em combinação 
com outras armas. Também não é fácil nem simples dispor dos recursos para desenvolver e produzir a variedade de equipamentos e armamentos necessários. Por isso, apesar de a meta mais ambiciosa no desenho das forças terrestres ser poder dispor de armas combinadas, admite-se que a falta de meios ou de pessoal suficientemente competente leve a não mais que a capacidade de combater usando armas apoiadas, armas alternadas ou mesmo armas isoladas. Na guerra, é necessário lutar com as forças que se tem, não com as que se desejaria ter.

Dessa forma, atender ao primeiro desafio no desenho de forças terrestres - o de escopo - significa poder buscar o máximo de capacidade no rumo de armas combinadas. É a partir desta questão que se apresentam as preocupações mais incisivas de desempenho comparado em relação ao oponente. Isso inclui tanto o desempenho de pessoal, em termos de capacitação, motivação e competências, quanto o de equipamentos e armamentos.

Por sua vez, o desafio da escala é pertinente ao número de coisas e pessoas e ao fluxo de produção e distribuição de tudo que se precisa ter para poder dispor da força. Aqui, as questões mais incisivas são quanto a possibilidades de produção, estoque e reposição de materiais e seus fluxos logísticos; e de recrutamento, treinamento e cuidado com pessoal e a formação de seus efetivos. Números são relevantes no espaço e no tempo: no espaço, eles dizem respeito a ter material e pessoal suficiente para permitir a sustentação da capacidade combatente no terreno; no tempo, para sustentar a luta enquanto perdurar o agir dos oponentes. É isso que se ganha ao atendê-lo.

É partindo dessa perspectiva que se pode compreender a centralidade da divisão (entre 10 mil a 20 mil combatentes) para o desenho das forças terrestres de uma sociedade que ambicione combater com armas combinadas. Trata-se do ponto ótimo em termos de escopo e escala, se comparado com a brigada (de 3 mil a 5 mil combatentes) ou com o corpo-de-exército nos EUA ou o exército numerado na URSS (de 30 mil a 60 mil combatentes). A partir dela se podem entender todas as considerações materiais de armamentos, de pessoal e de comando. Tudo o mais existe ao seu redor para permitir, apoiar ou complementar sua ação. 
Esse estado da arte é fruto das muitas combinações de diferentes alternativas de escala e escopo, muitas contraditórias entre si, havidas desde o Século XVIII, quando o problema das armas combinadas se pôs de maneira clara diante da necessidade de um desenho deliberado para as forças terrestres. Em síntese, esse desenho resulta da composição de um acervo de saberes partilhado, um determinado estado da arte bélico, e o contexto e a situação de uma dada sociedade (DELBRÜCK, 1990; HAYTHORNTHWAITE 1997; HOUSE, 2002; WILSON 1998; KEDZIOR, 2000).

Esse é o rumo da exposição do desenho das divisões ditas pesadas, motorizadas e com tanques, da URSS e dos EUA na Segunda Guerra Mundial (1939-1945 na Europa) e no auge da Guerra Fria (c. 1985). O tanque, veículo blindado motorizado, foi uma parte da solução em resposta ao impasse da guerra de trincheiras. Era, na origem, uma casamata móvel, que podia atravessar a terra de ninguém entre as trincheiras oponentes sendo imune aos disparos de fuzis e metralhadoras e aos fragmentos de granadas de artilharia. Associado a táticas de infiltração da infantaria (ENGLISH; GUDMUNDSSON, 1994) e de articulação coordenada com a artilharia (BAILEY, 2003; GUDMUNDSSON, 1993), o tanque correspondeu ao cerne de um redesenho do que seriam e poderiam vir a ser as armas combinadas modernas (GUDMUNDSSON, 2004).

Os resultados observados em experimentos e as visões de um futuro marcado pela motorização e os tanques ao longo das décadas de 1920 e 1930 produziram diferentes propostas de como se preparar e conduzir uma forma de guerrear 'blindada'. Esta revelou-se capaz de dar imensa vantagem na campanha da França de 1940, onde as divisões blindadas alemãs (Panzerdivisionen) demonstrariam o potencial da chamada "guerra relâmpago" (Blitzkrieg), que perfurava as linhas oponentes para desconjuntar suas armas combinadas e, potencialmente, paralisava suprimentos, comando, cidades, indústrias, governos (BELLAMY, 2015; DEIGHTON, 2000; HOUSE, 2002).

Durante a Guerra Fria se observariam questões semelhantes com o desenvolvimento do helicóptero, a começar por entender como aproveitar essa melhora em desempenho técnico para produzir vantagem combatente. Embora 
helicópteros não tenham tido o mesmo significado que a motorização e os tanques, eles acrescentavam alternativas em termos de possibilidades de uso.

Helicópteros podiam ser configurados como veículo de reconhecimento e guia de fogos, como 'tanque', ou seja, artilharia móvel pelo ar, ou 'caminhão', para transporte de tropas e materiais (GUNSTON, 1999; MCGOWEN, 2005; MILLER, 2001). A sua velocidade de deslocamento thes permitia estar em toda parte, cruzando a linha de contato entre as tropas para agir na retaguarda oponente. Helicópteros mudavam a geometria do enfrentamento e podiam interferir em seu desenrolar de novas maneiras. Podiam agir desde direções inesperadas, idealmente desde a retaguarda do oponente, atravessando qualquer terreno e ignorando todos os obstáculos. Podiam espreitar desde um ponto cego e caçar alvos discriminadamente, fosse guiando artilharia centralizada, atacando com mísseis ou canhões de elevada precisão ou pondo no terreno tropas ou materiais (BOYNE, 2011).

Esperava-se ainda que pudessem fazer um grande número de sortidas, dia ou noite, operando com fluência pela neblina e mesmo, com algumas cautelas, sob chuva ou neve. Diante dessas possibilidades, exigiram adaptações e ajustes em práticas e condutas, mas não chegaram a reconfigurar o estado da arte bélico a ponto de exigir novo enquadramento das armas combinadas ou deslocar o ótimo de escala e escopo da divisão para outro desenho (ALLEN, 1993).

De outra forma, em 1941, URSS e EUA se viram diante da realidade disruptiva decorrente da motorização e dos tanques, e foi a partir dela que passariam a considerar o desenho de suas próprias divisões pesadas.

\section{As Divisões Pesadas da URSS e dos EUA em 1945}

\subsection{Os Corpos de Tanques e Mecanizado Soviéticos}

Em 22 de junho de 1941, o grande sonho da URSS de ter um exército no auge do estado da arte em desenho, armamentos e capacidades teve de ser abruptamente abandonado diante do furor da invasão nazista. As suas forças mais bem preparadas desde antes da guerra, ao redor de 4,2 milhões de 
combatentes, foram praticamente aniquiladas. Em lugar do sonho, sobraram o desespero diante da constatação de que era impossível dar conta do oponente e a determinação de lançar tudo o que tivessem contra a ameaça existencial que rasgava território soviético adentro e cuja sombra se projetava até Moscou.

A imensa reserva, talvez de 8 milhões de combatentes, foi imediatamente posta em campo. Embora tivesse de lutar com equipamentos mais antigos, a força ainda buscava se conformar aos desenhos e às condutas combatentes mais modernas. Mas as perdas colossais que seguiam sofrendo apontavam para uma derrocada completa. Em resposta, mais e mais tropas foram treinadas e lançadas à luta o mais rapidamente possível, mordendo fundo nos estoques de suprimentos e limitando em escopo as capacidades que podiam aprender. Tendo perdido a maior parte de seu território europeu, a URSS teve de produzir milagres para evacuar suas fábricas, reconstituí-las na Sibéria e conseguir mantê-las funcionando (GLANTZ 1991a, GLANTZ; HOUSE, 2015).

Os soviéticos só contiveram o invasor por uma largueza de espírito incomum e pelo abandono deliberado de qualquer ambição de sofisticação ou atualidade no desenho das suas forças. A sua solução em termos de desenho foi adotar o exército numerado, ao qual se subordinavam unidades combatentes largamente autônomas. Era um retorno a fundamentos. Cada unidade combatente passou a ter um armamento preponderante. A conduta do combate foi simplificada e a carência de pessoal qualificado tornava necessário subordinar muitos aos poucos efetivamente competentes para comandar. Embora as tropas fossem bem treinadas no manejo dos armamentos e estivessem verdadeiramente empenhadas na luta, não se tinha muito mais do que isso. Além disso, a autonomia das unidades combatentes não era gratuita: as limitações na estrutura de comando dos exércitos numerados obrigavam cada unidade a lutar por si (DUNNIGAN, 1977; GLANTZ, 2001).

Conscientemente, abandonou-se qualquer tentativa de armas combinadas (BELLAMY, 2008; GLANTZ; HOUSE, 2015; ELLIS, 1993). Cada unidade era de uma única arma que vinha enfrentar o oponente como arma isolada. Na defesa, escalonavam-se diferentes unidades até que desse certo, ou não. Havia mais êxito em três circunstâncias: ao defenderem posições fortificadas e camufladas 
do que em campo aberto; na lama ou neve do que em bom tempo; quando o oponente enfrentava dificuldades de reposição de suprimentos. No ataque, e se contra-atacou desde a primeira hora, o plano dado pelo comando do exército numerado tinha de ser seguido à risca: as unidades eram lançadas em sucessão cronometrada contra o oponente, precedidas, quando possível, de barragens de artilharia preparatórias, e ambicionavam combater como armas alternadas. Tais ataques geralmente davam errado, a não ser que o oponente estivesse combalido pelo inverno ou pela falta de suprimentos. E assim morriam muitos mais soviéticos do que invasores; mas morriam invasores em quantidades suficientes para diminuir sua capacidade ou vontade de lutar. Para os soviéticos, lutar demandou perseverar, contando com a imensidão do seu território, defendendo-se desesperadamente e atacando com abandono, enquanto aceleravam a mobilização de mais e mais forças para soterrar os invasores com números. Eles aceitavam a desvantagem relativa das armas isoladas ou alternadas porque só conseguiam lutar assim.

Em fins de 1942, restava claro que a URSS não seria sobrepujada; faltava saber com quanto sacrifício e esforço os invasores seriam expulsos. Para poder atacar com expectativa de sucesso a custos aceitáveis, reconheceu-se que era preciso buscar armas combinadas uma vez mais. Entretanto, isso significava ter de centralizar e complicar para se fazer capaz de articular e associar as diferentes armas sob escalões de comando próximos ao combate, permitindo assim aproveitar oportunidades e dar conta de dificuldades não previstas nos planos cronometrados dados pelo comando do exército numerado. Para tanto, em setembro de 1942, criaram-se dois tipos de organização de tamanho divisional, denominados corpos, num exagero de nomenclatura que não correspondia ao seu tamanho real (DUNNIGAN, 1977; GLANTZ, 2001; GLANTZ et al., 2004; GLANTZ; HOUSE, 2015).

O primeiro foi o Corpo de Tanques (Figura 1), composto de três unidades chamadas brigadas de tanques que combinavam tanques médios e leves com infantaria armada com submetralhadoras; uma brigada de infantaria motorizada; um regimento de tanques pesados; e regimentos e batalhões de diferentes armamentos de artilharia e nominalmente de outras armas: engenharia, 
antitanque, reconhecimento, antiaérea e sinais. Foi possível ter mais de três dezenas de corpos de tanques com aproximadamente 12 mil combatentes, 2,4 mil de infantaria, 240 tanques e 150 peças de artilharia e de lança-foguetes cada um (DUNNIGAN, 1977; ZALOGA; NESS, 1998). Em linhas gerais, era uma divisão blindada semelhante às de outros países, com duas grandes vantagens e duas grandes desvantagens em relação a elas.

Figura 1 - Corpo de Tanques soviético (1942-1945)

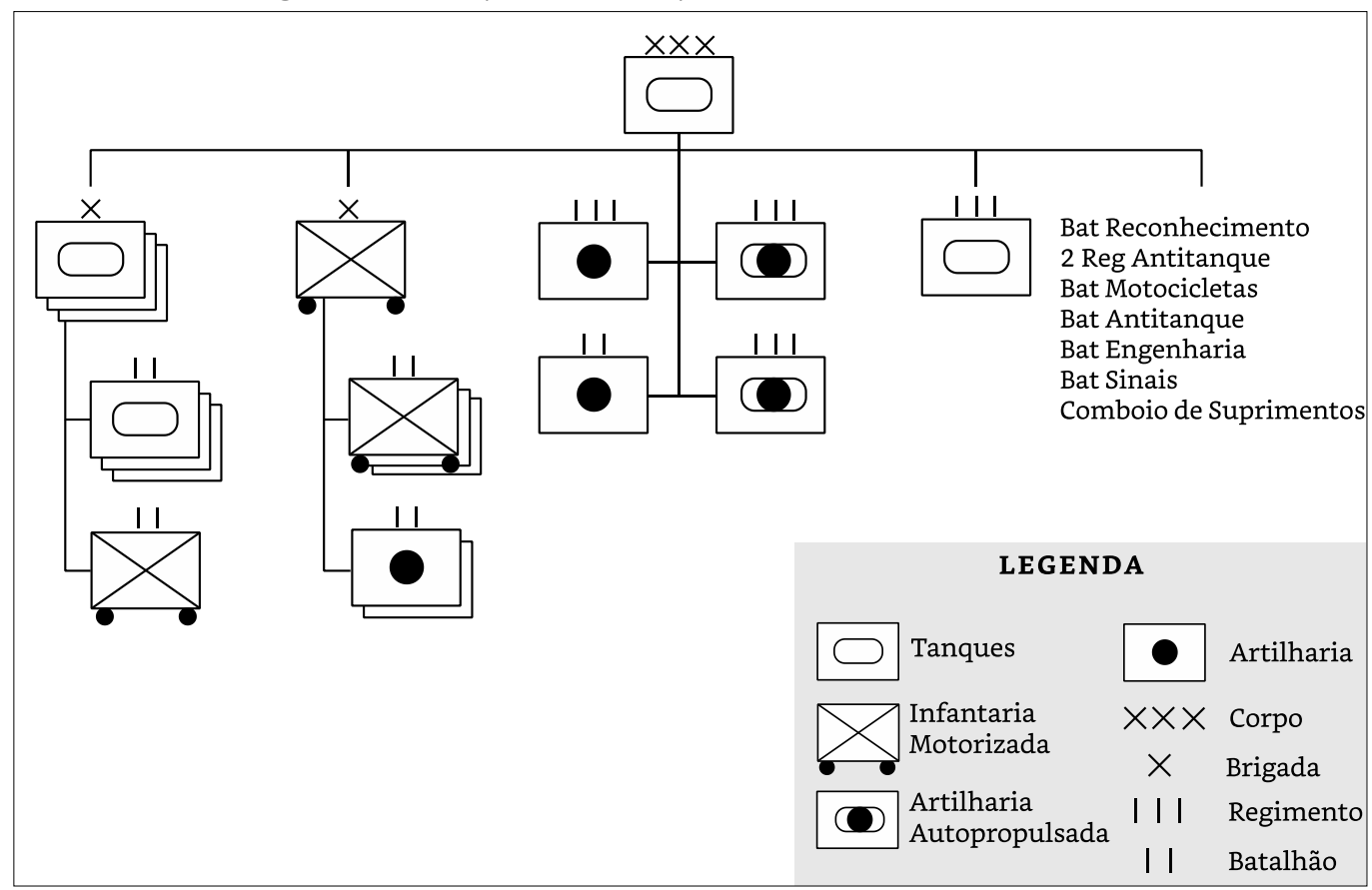

Fonte: Adaptado pelos autores a partir de Dunnigan, 1977, p. 120.

A primeira vantagem deste desenho organizacional era que os soviéticos dispunham de tanques suficientes para manter seus corpos de tanques completos e para combater com superioridade numérica de até 2:1 em comparação com a mais forte das divisões blindadas alemãs. Com isso, podiam contrapor sua vantagem numérica à superioridade de desempenho dos alemães, derramando contra o oponente uma enxurrada de tanques para além da capacidade antitanque de qualquer posição individual na linha de frente. Também podiam fazer o mesmo contra tropas alemãs que viessem a ser apanhadas na retaguarda depois de uma ruptura bem-sucedida.

A outra vantagem era que os soviéticos sabiam profundamente o quão vulneráveis eram os tanques oponentes sem apoio próximo da infantaria. Como 
seus caminhões não tinham capacidade fora-de-estrada, eles eram usados para conduzir tropas de reposição, enquanto combatentes de infantaria seguiam encarapitados nos próprios tanques. Isso acabou dando às forças soviéticas capacidade para atacar arranjos defensivos, rompê-los e se lançar além, confiantes de que não seriam barrados por emboscadas da infantaria oponente. Uma vez tomado o objetivo, ele poderia ser defendido pela brigada de infantaria motorizada que seguia com cada corpo de tanques.

A primeira desvantagem era a falta de pessoal qualificado em número suficiente. Embora o número de peças e guarnições fosse adequado, cada equipe de artilheiros era responsável por quatro conjuntos delas ou mais de uma só vez, o que restringia seu uso ao tiro contra alvos que podia enxergar por si. Dessa forma, não se tinha artilharia moderna, centralizada, acionada por rádio, mas sim peças usadas como armamentos pesados. Em lugar de armas combinadas, tinha-se, na melhor das hipóteses, armas apoiadas, ou aquilo que os soviéticos passariam a chamar de todas-as-armas. A segunda era que não havia suprimento motorizado capaz de manter o corpo de tanques continuamente abastecido depois que ele avançasse para além das linhas do oponente. Só se podia ter o suficiente para reposição de munição para até quatro dias de combate e até dois reabastecimentos de combustível para os tanques. Isso limitava o alcance das ofensivas bem-sucedidas dos corpos de tanques em função da ausência de estradas e do grau de dificuldade do terreno a algo entre $150 \mathrm{~km}$ e $200 \mathrm{~km}$.

Essas desvantagens eram particularmente consequentes quando um corpo de tanques encontrava resistência respaldada por artilharia centralizada na retaguarda inimiga depois da ruptura. Diante disso, suas opções eram limitadas. Podia tentar irromper, o que era muito difícil e arriscado na ausência de uma barragem preparatória. Podia empenhar e consumir sua infantaria, o que sacrificava a possibilidade de defender o que viesse a ser tomado, deixava o corpo de tanques enfraquecido e o tornava presa fácil para o inevitável contraataque do oponente com armas combinadas. Podia tentar mudar radicalmente de direção para contornar a resistência, mas isso demandava um excedente normalmente inexistente de combustível e a fortuna de se ter uma estrada pela qual seguir. Ou podia recuar e esperar reforços de outras unidades, o que 
significava encerrar a ofensiva, sabendo que para retomá-la teria de começar novamente e se exigiria toda a elaboração de uma barragem preparatória e de pelo menos um corpo de tanques completo.

O segundo desenho era bem mais sofisticado e recuperava a ambição do pré-guerra: o Corpo Mecanizado (Figura 2). Este foi o maior desenho de unidade praticado pelos soviéticos na Segunda Guerra Mundial, com três brigadas de infantaria motorizada, uma brigada de tanques, mais regimentos e batalhões de artilharia e de outras armas: engenharia, antitanque, antiaérea, sinais. Tinha aproximadamente 17,5 mil combatentes, 7 mil de infantaria, 120 tanques (os mais avançados disponíveis) e 120 peças (idem) cada (DUNNIGAN, 1977; ZALOGA; NESS, 1998). Nunca foi possível ter mais do que uma dúzia dos corpos mecanizados por carência de pessoal especializado. Partilhavam das vantagens e desvantagens de corpos de tanques com algumas diferenças importantes.

Figura 2 - Corpo Mecanizado soviético (1942-1945)

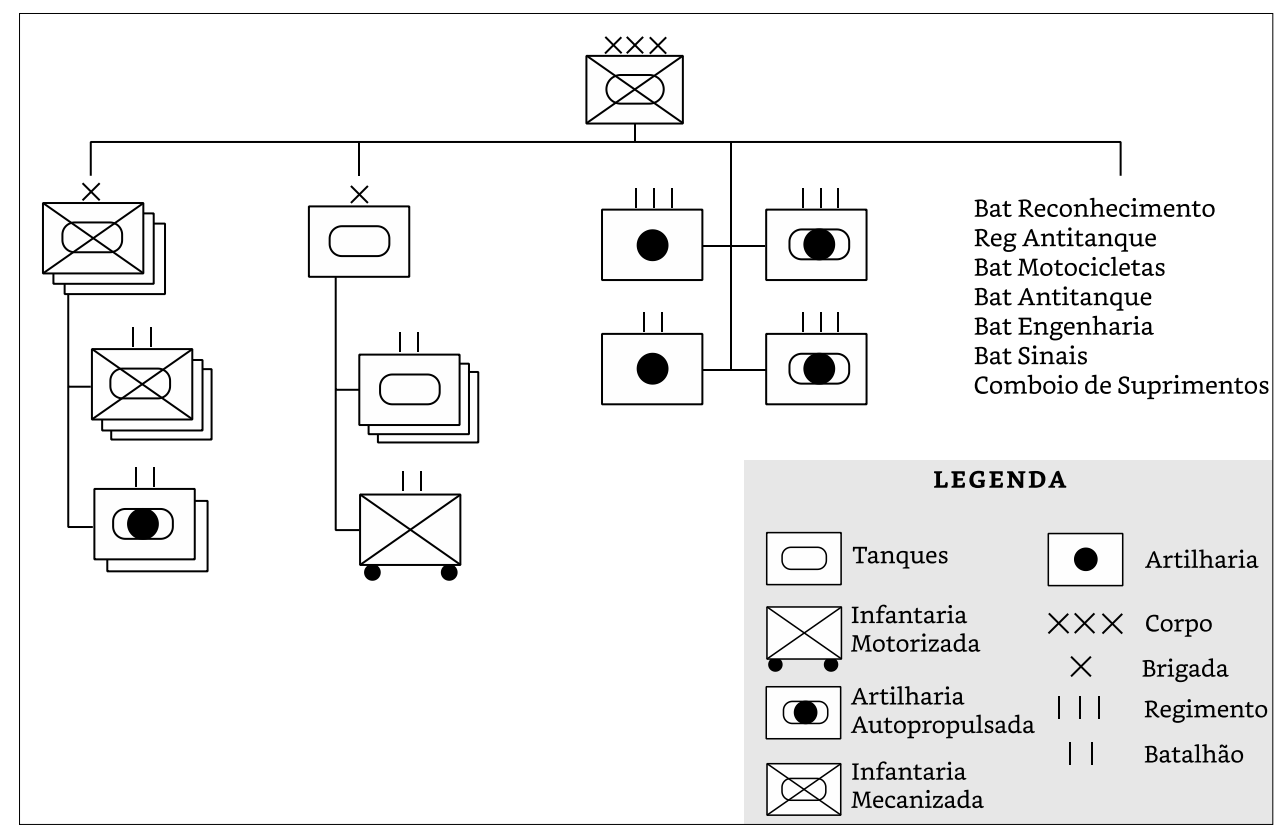

Fonte: Adaptado pelos autores a partir de Dunnigan, 1977, p. 121.

Os soviéticos dispunham de tanques suficientes para manter seus corpos mecanizados atualizados e completos. Além disso, eles também dispunham de caminhões fora-de-estrada e meias-lagartas (estas em número insuficiente) para conduzir a infantaria. Quase todos os veículos dos corpos mecanizados haviam sido fabricados nos EUA e apresentavam vantagens relativas de confiabilidade, 
economia de combustível e alternativas de uso se comparados aos veículos dos corpos de tanques (ELLIS, 1993). Enquanto a infantaria no corpo de tanques se mantinha próxima por meio de um expediente (encarapitar-se nos tanques), nos corpos mecanizados ela podia progredir no mesmo passo e ritmo todo-terreno dos tanques em seus meias-lagartas e nos melhores modelos de caminhões fora-de-estrada fabricados nos EUA. Isso viabilizava diversas possibilidades combatentes de armas apoiadas de infantaria, tanques e artilharia como armamento pesado. Isso também viabilizava a proximidade entre as unidades e, portanto, o uso mais eficaz de reconhecimento, antitanque, antiaérea, engenharia e especialmente, sinais - um corpo mecanizado completo era a única unidade soviética que dispunha de um número suficiente de rádios.

Mas ainda assim não se tinha artilharia centralizada. Nem mesmo os corpos mecanizados puderam contar com artilheiros suficientes. De forma comparável ao corpo de tanques, havia um número adequado das melhores peças, mas não se podia usá-las como armas combinadas. Só se podiam ter, diante da falta de pessoal qualificado, armas apoiadas, ou novamente todas-asarmas. Embora também sofressem com a falta de suprimento motorizado do corpo de tanques, os corpos mecanizados demandavam menos combustível, porque meias-lagartas e caminhões consomem uma fração do consumo de tanques para cobrir a mesma distância. Além disso, uma mesma quantidade de munição rende mais quando usada por um efetivo maior de infantaria. Essas vantagens relativas permitiam que o corpo mecanizado não dependesse tanto de reabastecimentos para continuar lutando na defesa do que tomasse. Agora, uma ofensiva bem-sucedida podia ir mais longe (250km a $300 \mathrm{~km}$ ) e não dependia tanto de uma estrada pela qual seguir.

Corpos mecanizados podiam lidar com oponentes respaldados por artilharia centralizada porque as suas capacidades todo-terreno permitiam alternativas de armas apoiadas, o melhor do todas-as-armas soviético. Podiam infiltrar-se, penetrar ou contornar posições das maneiras que só a infantaria e a engenharia permitem, com apoio de armamento pesado e tanques. Podiam obter uma brecha ou aceitar combate móvel contra forças blindadas oponentes com infantaria, artilharia e até antitanque apoiando os tanques. Podiam dar conta de 
posições oponentes na retaguarda e ainda dispor de infantaria suficiente para defender o que ocupassem mesmo depois de ter lidado com elas. Todavia, os soviéticos entenderam que a verdadeira vocação do corpo mecanizado era a exploração da ruptura para assenhorar-se de uma posição vital, usualmente um nó ferroviário.

Com infantaria mecanizada todo-terreno, tanques e armamentos pesados, corpos mecanizados podiam enfrentar o que fosse enviado para retomar o que haviam conquistado com todas-as-armas. Entretanto, por mais que representassem um avanço em comparação com os corpos de tanques, os soviéticos estavam cientes de que não teriam suprimento motorizado adequado durante a guerra e que as suas limitações de pessoal provavelmente significavam que não se poderia ir além do todas-as-armas. As suas restrições de escopo eram de fato consequentes.

E com isso se chegou a Berlim.

Em 9 de agosto de 1945, a URSS invadiu a Manchúria japonesa numa demonstração da sua capacidade para lançar operações em larga escala na linha do que havia sonhado no pré-guerra. Foram empregados 1,5 milhão de combatentes, 5,5 mil tanques e quase 30 mil peças de artilharia contra o Exército do Kwantung, o mais poderoso e melhor equipado entre todos os exércitos japoneses. Este contava com 700 mil combatentes, 1,2 mil tanques e 5,4 mil peças de artilharia. Como parte da preparação para a operação, o 6o Exército de Tanques de Guardas foi reestruturado (e todos os corpos de tanques e mecanizados que o compunham), já considerando que se estava diante do modelo de desenho das forças no pós-guerra. Foram incorporados tanques, infantaria e peças, número e capacidades, para permitir o todas-as-armas em todas as brigadas (GLANTZ, 2003).

Com maior abundância de material, pessoal e tempo de preparo, foi possível incrementar o uso de artilharia, mas não a ponto de permitir armas combinadas. Mesmo assim, melhorou-se o que era possível melhorar e pôde-se ter um comboio de suprimento pensado para permitir um avanço de mil quilômetros, distância duas vezes e meia maior que a de qualquer ofensiva anterior, e 200 km superior à localização do objetivo. O resultado foi acachapante: 
em menos de duas semanas, a logística do Exército do Kwantung tinha sido destruída e o colapso japonês foi completo.

Iniciou-se de pronto um processo de ajuste ao redor do desenho bemsucedido da Manchúria. A capacidade desse arranjo consubstanciava a materialização da superioridade soviética para projetar força em qualquer direção ao alcance das suas bases, por exemplo, a costa atlântica da França desde a Alemanha Oriental.

Entretanto, o todas-as-armas dependia da concentração articulada da força, em grandes quantidades. E aí houve a bomba atômica... para os soviéticos, uma verdadeira revolução nos assuntos militares, porque concentrar passaria a significar se tornar um alvo fácil e vulnerável. Toda essa aparente superioridade, agora convencional, parecia ter se esvaído. Foi diante dessa perspectiva, e de tudo que ela parecia demandar em termos de mudança do entendimento construído até então, que os soviéticos viriam a pensar no desenho de suas divisões para a Guerra Fria (GLANTZ, 2010).

\subsection{A Divisão Blindada dos EUA}

Até 8 de dezembro de 1941, os EUA haviam acumulado vinte anos de reflexão sobre a modernização do seu projeto de força terrestre. Ela se orientava por uma meta tida como amplamente hipotética de transformar, em escala e escopo, um exército com menos de 130 mil efetivos, movido principalmente a cavalo e organizado em cinco divisões dispersas em regimentos numa instituição capaz de pôr em campo 10 milhões de efetivos, centenas de divisões motorizadas e combater com armas combinadas. Mas a participação dos EUA na Segunda Guerra Mundial não se limitava a combater as forças do Eixo em conjunto com a Grã-Bretanha e a União Soviética. Os estadunidenses também se fizeram responsáveis por armar e suprir o esforço de guerra dos países aliados e abastecer suas populações civis, o que demandaria escopo, abrangendo capacidades combatentes e não combatentes e escala em absolutamente tudo.

Que tivessem conseguido superar a meta originalmente hipotética em número e capacidade combatente e dar conta das suas incumbências adicionais, 
também se deveu à largueza de espírito, de empenho e sacrifício. Sobretudo desde o ataque a Pearl Harbor, quando se consolidaram a mobilização de toda a nação em torno do esforço de guerra e o engajamento direto de seus cidadãos nele, fosse se alistando nas forças, fosse trabalhando na indústria. Também ajudou que as pessoas responsáveis pelo planejamento de como combater, suprir e abastecer numa escala jamais vista pudessem contar com a experiência acumulada na tropa desde a Primeira Guerra Mundial e fora das forças no processo acelerado de industrialização dos Estados Unidos durante o mesmo período. Essa experiência ensinava que se podia sonhar sim, mas apenas com aquilo cuja viabilidade e utilidade se pudessem testar, e desde que viesse a estar disponível a tempo de contribuir com o esforço de guerra.

Para que pudessem modernizar o seu projeto de força terrestre, os EUA sabiam que teriam de priorizar, em termos de escopo, o desenvolvimento das capacidades organizacionais necessárias para viabilizar o suprimento continuado das suas forças independentemente da distância entre os teatros operacionais em que atuariam e a sua base industrial. Havia duas realidades inalteráveis: a primeira, os EUA eram separados da Europa por um oceano; a segunda, a infraestrutura logística no teatro europeu era insuficiente, na melhor das hipóteses, e inexistente, na pior, e não seria possível substituí-la em tempo hábil, antes que a guerra terminasse. Dessa forma, havia limites reais ao que se podia transportar em termos de escopo, considerada a demanda de coordenação e controle de múltiplas interfaces logísticas, e de escala, consideradas as demandas simultâneas e concorrentes das suas próprias forças, das forças aliadas e das suas populações civis na mesma cadeia de suprimentos (COAKLEY; LEIGHTON, 1968; GREENFIELD; PALMER; WILEY, 1987; GROPMAN, 1997; LEIGHTON; COAKLEY, 1955 ).

Por conta disso, os EUA consideravam a questão da confiabilidade dos armamentos como um empecilho significativo para que pudessem fazer uso amplo da motorização e dos tanques. Não adiantava ter os modelos mais avançados de veículos combatentes se eles não podiam ser mantidos continuamente em condições operacionais. Eles tinham de se manter funcionando sem o consumo constante de peças de reposição ou de tempo e 
empenho exagerados das equipes de manutenção. Cientes das implicações organizacionais de orientar suas escolhas em função da confiabilidade de seus armamentos e equipamentos, os EUA construíram instâncias de consulta e governança civil-militares para facilitar a troca de informações entre os dois grupos e desenvolveram sistemas robustos de teste e avaliação de armamentos (COAKLEY; LEIGHTON, 1968). Além disso, os estadunidenses puseram em campo o arranjo de controle de estoques mais avançado do mundo. Com ele, podiam saber exatamente o que tinham, onde estava e como transportá-lo de forma eficaz. Isso permitiu manter as suas forças supridas diante de condições extraordinárias, enquanto eram forçados a reconhecer, mesmo assim, que a falta de escala na sua cadeia logística impediu que recebessem, em tempo hábil, todos os suprimentos que poderiam ter vindo a receber (OHL, 2020).

Entretanto, o principal desafio dos EUA na reformulação das suas divisões pesadas foi mesmo corporativo. Internamente não havia consenso sobre como fazer uso dos tanques, e cada arma buscou defender uma solução que desse conta de seus próprios interesses. A cavalaria desejava seguir exatamente como antes, trocando cavalos por carros blindados e tanques leves para reconhecer e fustigar o oponente em linhas de patrulha, e por tanques leves e mesmo médios para explorar a ruptura e perseguir o oponente em retirada até seus centros de comando e controle. Diante disso, a infantaria queria seus próprios tanques, não só para vencer as casamatas oponentes, mas também para caçar tanques, já que a cavalaria não parecia particularmente preocupada com os tanques oponentes mesmo sabendo do que eram capazes de fazer. Ao fim, a arma blindada (armor) acabou por substituir a de cavalaria. Ela tinha a ambição de ser a arma de armas combinadas modernas, incluindo tanques, infantaria e artilharia, além de engenharia, antiaérea, antitanque, sinais e logística. Seu papel seria irromper pelas linhas oponentes e explorar a ruptura (GILLIE, 1947; GREENFIELD; PALMER; WILEY, 1987; HAWKINS, 2013; HAWKINS; CARAFINO, 1997; KEDZIOR, 2000).

Em 1942, fez-se uma primeira tentativa de desenho da divisão pesada. Sabia-se que a maioria das tropas nas divisões de infantaria nunca seria motorizada, não porque faltassem bons caminhões, mas porque seria 
logisticamente impossível abastecê-los: não havia nem espaço de transporte suficiente para caminhões e suas peças de reposição, principalmente pneus, nem lugar para estocar todo o seu combustivel na Grã-Bretanha (COAKLEY; LEIGHTON, 1968; LEIGHTON; COAKLEY, 1955). Quis-se uma divisão blindada capaz de realizar todas as tarefas imaginadas pela cavalaria, pela infantaria e pelos proponentes da guerra blindada. Ela veio a contar aproximadamente com 15 mil combatentes no total, dos quais 1,5 mil de infantaria, 700 meias-lagartas, 390 tanques, 48 peças de artilharia e 40 carros blindados (ZALOGA, 2006). O número particularmente baixo de combatentes de infantaria demonstrava que os EUA, como diversos outros países, também haviam subestimado quantos deles se faziam necessários para se poder lutar com armas combinadas.

A disfuncionalidade dessa estrutura divisional se revelaria no Norte da África em 1942 e na Itália em 1943.

Primeiramente, durante o combate, a divisão tendia a se rearranjar em brigadas com comando fragmentado, que disputavam a mesma artilharia e sofriam conjuntamente da falta de infantaria para guarnecer os tanques (ZALOGA, 2006). Em segundo lugar, havia mal-entendidos táticos diversos, desde não saber aproveitar a superioridade de fogo que a infantaria mecanizada podia conferir, passando por esquecer que os tanques não eram cavalaria, e que por isso não deveriam seguir condutas combatentes antigas; a até não saber fazer uso da artilharia centralizada, por exemplo. Finalmente, havia problemas de desenho, de organização e suprimento (ATKINSON, 2002; ZALOGA, 2006). Em suma, dispunha-se até de armas combinadas, mas as condutas ainda estavam muito distantes do auge do estado da arte.

Diante disso, os estadunidenses também tiveram de recorrer a fundamentos. A sua experiência combatente na Primeira Guerra Mundial haviase dado diante de restrições de escala e escopo significativas. Por falta de produção e de capacidade combatente, tiveram de contar com armamentos e seguir os arranjos de seus aliados. Isso formou uma geração de veteranos, base do oficialato e do generalato responsáveis pelo preparo e pela conduta na Segunda Guerra Mundial, muito ciosa da relevância de duas questões: saber 
preparar o esforço de guerra e saber projetar desenhos organizacionais como parte fundamental de um projeto de força terrestre.

Esse entendimento levou a um aprimoramento na capacidade estadunidense de diagnosticar e atender carências de equipamento e de organização que foi posta em prática ainda na Primeira Guerra e que não foi esquecida nos anos seguintes. Diante da necessidade de desenvolver novas condutas combatentes e de capacitar as tropas adequadamente, produziram-se milhares de materiais, inclusive as centenas de filmes de instrução, informação, conformação e mobilização, destinados desde aos combatentes na linha de frente, passando por toda a retaguarda militar, fabril, agricultural, até aos cidadãos nos cinemas dos EUA.

Em 1943, chegou-se ao desenho da Divisão Blindada (Figura 3), guiado pelo desejo de explorar ao máximo a sua mobilidade todo-terreno e emulando a lógica das divisões blindadas alemãs e britânicas, que vinham diminuindo em tamanho. Uma divisão grande demais em movimento punha partes para além do alcance fácil do rádio, fazendo com que perdessem a capacidade de acionar a artilharia centralizada. Era, de fato, uma divisão blindada modesta, com dois comandos de combate, que podiam compor os seus três batalhões de infantaria em meiaslagartas e três batalhões de tanques com antitanque, antiaéreo e artilharia conforme a necessidade. Cada divisão contava ainda com um batalhão de reconhecimento, outro de engenharia blindada e uma generosa dotação de armas de apoio: sinais, antiaérea, apoio médico e transporte. Somava 10,5 mil combatentes, 500 meias-lagartas e 3 mil combatentes de infantaria, 250 tanques, 72 peças de artilharia e 54 carros blindados. Além disso, tinha em seus caminhões todo-terreno a capacidade de contar com um comboio de suprimentos pensado para $500 \mathrm{~km}$ mesmo durante a batalha, capaz de prover quatro cargas de combustível para cada veículo e oito dias de munição. Esse comboio se revelou redundante diante da capacidade do suprimento motorizado estadunidense, cuja audácia e flexibilidade the permitia seguir ruptura adentro como se fizesse parte das forças combatentes (ZALOGA, 2004). 
Figura 3 - Divisão Blindada estadunidense (1943-45)

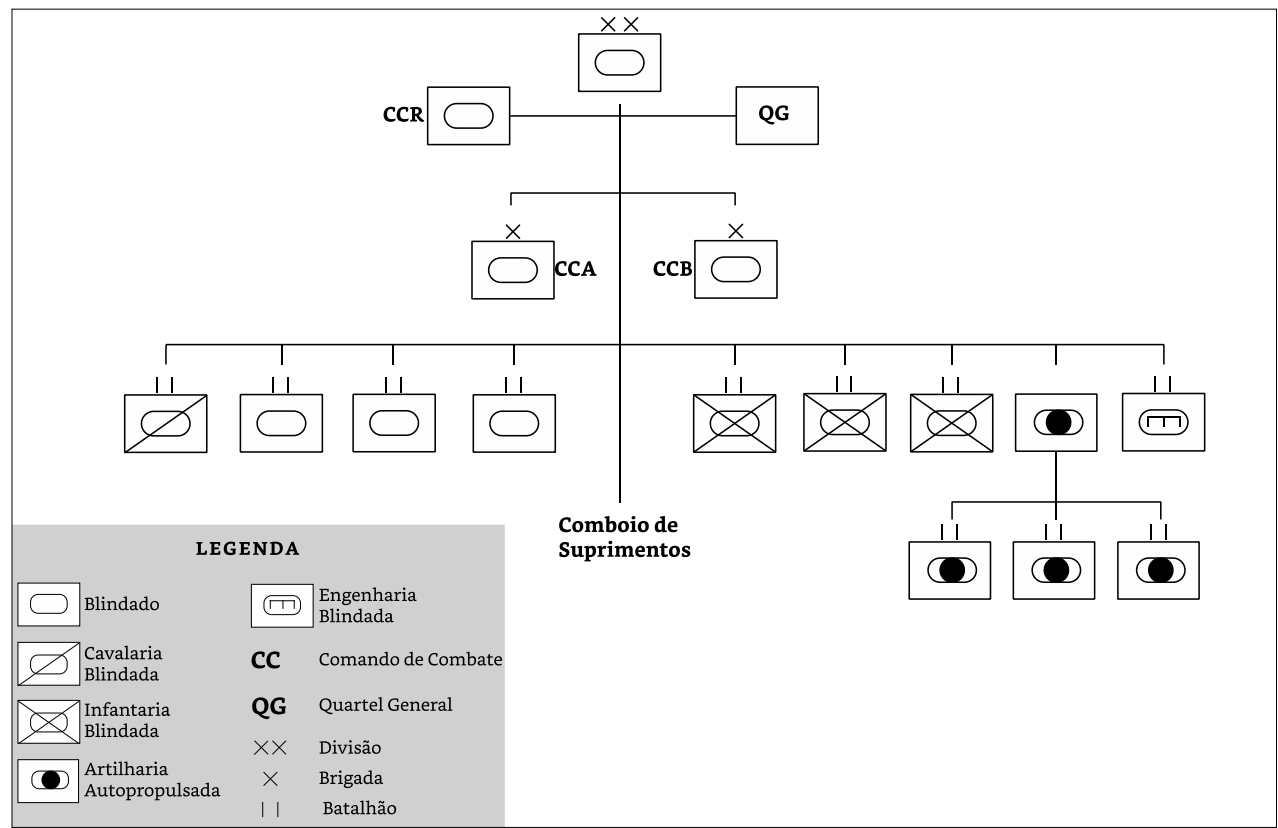

Fonte: Adaptado pelos autores a partir de Zaloga, 2004, p. 13.

A ênfase - que já se podia medir em décadas - nos problemas de escopo em termos da formação das capacidades organizacionais necessárias para preparar, suprir, coordenar e comandar as forças de combate, e para treiná-las nas condutas combatentes, insistentemente produziu uma dinâmica adaptativa nas forças dos EUA inimitável por qualquer outro país, que viria a potencializar o que se podia fazer com armas combinadas e alargar o estado da arte (STEWART, 2010; WILSON, 1998; ZALOGA 2004, 2006). Cada divisão blindada desdobrava com fluência seus batalhões em comandos de combate pensados para a batalha nas mais diferentes maneiras. Havia uma abundância de conhecimento partilhado e disponível que viabilizava um processo de educação continuada a todos que precisassem aprender. Com isso, a capacidade de lutar lado a lado se potencializava diante das recombinações de combatentes e armamentos. E ainda se tinha o 'ás na manga': cada divisão era capaz de mobilizar uma forte força-tarefa a partir do que tinha de melhor em equipamento, armamentos e pessoal, em suma armas combinadas, que podia ser posto diretamente sob o comando do QG da divisão.

Entre o desembarque na Normandia, em 6 de junho de 1944, e o Dia da Vitória na Europa, em 8 de maio de 1945, as forças blindadas americanas 
seguiram no mesmo ritmo de aprendizado e adaptação que tinham demonstrado na África e na Itália. Tinham prioridade de pessoal, recursos e conexão com a retaguarda industrial e a boa-vontade do serviço de suprimentos, tinham seus especialistas em mecânica e combate. As inovações técnicas e de conduta se difundiam pelas unidades quase tão rapidamente quanto surgiam (JARYMOWYCZ, 2008; ROTTMAN, 2007; 2008; 2011; ZALOGA, 2011). As touceiras da Normandia eram intransponíveis para tanques; inventou-se o rhino, lâminas que permitiam vencê-las, em menos de um mês desde a chegada, e seu uso se disseminou para as demais unidades em não mais que duas semanas. Praticouse, nos primeiros dois meses de luta, contra as forças alemãs densas e fortemente blindadas, tudo o que se podia pensar em termos de armas combinadas, integrando artilharia e apoio da aviação, com seus comandos articulando batalhões contra o melhor do oponente para produzir efeitos desconcertantes, como só divisões capazes de todo-terreno com um suprimento motorizado (e aéreo) eram capazes de fazer.

Rompida a frente e na corrida desde a França até a Alemanha entre julho e novembro de 1944, contra as retaguardas e folgas de um oponente em retirada, reinventaram-se as armas combinadas mais uma vez. As vanguardas seguiam como armas combinadas sob a cobertura de aeronaves que se alternavam em ponto de táxi enquanto houvesse luz do dia. Quando os alemães desfecharam a contraofensiva nas Ardenas, em dezembro de 1944, descobriu-se que as divisões blindadas estadunidenses eram capazes do feito logístico e combatente de se reorientarem drasticamente em dias, e não nas semanas previstas nos manuais. Mas foi na luta nas cidades e contra as fortificações na própria Alemanha que se teve o auge das armas combinadas nas forças dos EUA. Aprendeu-se a isolar o oponente de seus suprimentos com fogos, a alavancar o ataque com uma súbita bordoada de impacto simultâneo, a participar com artilharia centralizada em armas combinadas na luta de casa em casa, de ponto forte em ponto forte, travando dezenas de combates em cada sortida. O que teria sido um obstáculo de semanas - como Berlim para os soviéticos - foi atravessado em dias.

Em suma, a partir de 1944, tudo o que se descobriu e aprendeu viria a produzir uma artilharia cada vez mais integrada, em que todas as peças ao 
alcance de um alvo podiam ser mobilizadas contra ele, independentemente da unidade à qual estivessem associadas. Podia-se responder ao chamado de uma tropa inicialmente com qualquer peça ao alcance, e depois vindo a somar mais e mais peças. Também era possível sincronizar os disparos de uma grande quantidade de peças fazendo com que atingissem o alvo simultaneamente para máximo impacto, com efeitos devastadores (BAILEY, 2003; EDGERTON 2011; GUDMUNDSSON, 1993).

Chegado o final da Segunda Guerra Mundial com a rendição japonesa, e diante da perspectiva de uso da bomba atômica no campo de batalha, o exército dos EUA se pôs a pensar sobre a questão como fazia habitualmente: perguntando-se qual seria o melhor desenho divisional para poder lidar com isso.

\section{A Frente Central, c. 1985}

\subsection{As Divisões de Rifles Motorizados e de Tanques da URSS}

A URSS terminou a Segunda Guerra Mundial com um imenso arsenal à sua disposição. Entretanto, a sua preocupação com o significado tático da possibilidade de emprego de armamentos nucleares durante a batalha levou a um intenso esforço de reequipamento durante a década de 1950, que ambicionava produzir veículos todo-terreno suficientemente blindados para resistir ao ambiente radioativo e em número suficiente para transportar toda a tropa. A isso se seguiu a postura de assertividade nos anos Brejnev, a partir de meados dos 1960 e até os 1970, quando se observou um crescimento substancial nas suas forças armadas, especialmente nas fronteiras com a OTAN, mesmo diante do declínio demográfico e da estagnação econômica que viriam a se acentuar no final desse período.

O que se plantara nos 1950 viria a dar bons frutos, ao menos inicialmente. A mecanização massiva do exército soviético para lidar com a radioatividade e o aumento contínuo no número de efetivos conferiram uma margem de superioridade às forças da URSS em comparação com às da OTAN. Como essas mudanças se deram diante da escolha deliberada por se manter o desenho 
organizacional herdado da Segunda Guerra Mundial, foi possível seguir de forma constante no processo de expansão das suas forças em termos de pessoal e equipamentos até que se vissem limitados por restrições demográficas e industriais (COCKBURN, 1983; GLANTZ, 2010; HOUSE, 2020).

As melhoras em armamentos e equipamentos entre 1945 e 1985 ampliaram o que se podia fazer com eles, mas não foram suficientes para reconfigurar as características de cada arma. Nem mesmo a incorporação de helicópteros e antiaérea de helicópteros levou a uma mudança no desenho organizacional das forças terrestres soviéticas. O seu foco era e continuava sendo se fazer capaz de lutar com armas combinadas, integrando infantaria, tanques, armamento pesado, peças de artilharia e antitanque, e agora, helicópteros. Dessa forma, os soviéticos apenas refinariam em detalhes os desenhos da Divisão de Tanques e da Divisão de Rifles Motorizados que haviam produzido a vitória na Manchúria em 1945 (ERICKSON, HANSEN; SCHNEIDER, 2019; GLANTZ, 2010; US ARMY, 1984; 1991).

Por volta de 1985, as forças de primeira linha da URSS tinham divisões e exércitos numerados com artilharia centralizada em cada divisão. O seu suprimento motorizado era capaz de apoiar o exército numerado em penetrações profundas no território europeu. Agora que tinham uma coisa e outra era possível voltar a ambicionar ter armas combinadas nas divisões. Com isso, as Divisões de Rifles Motorizados assumiram o papel combatente principal. Sua destinação era lutar, fosse para defender, fosse para atacar e produzir a ruptura da linha oponente. As Divisões de Tanques passaram a ser os instrumentos de exploração da ruptura, penetrando para além das linhas oponentes (COCKBURN, 1983; ISBY, 1988; ERICKSON; HANSEN; SCHNEIDER, 2019; US ARMY, 1991).

A Divisão de Rifles Motorizados (Figura 4) correspondia a 150 das 210 divisões que comporiam o Exército Soviético, com efetivo de 13,5 mil combatentes, 4 mil combatentes de infantaria, 270 tanques, 150 peças e lançafoguetes, 130 mísseis antitanque e 20 helicópteros cada uma (ISBY, 1988; US ARMY, 1991; VVAA, 2011). 
Figura 4 - Divisão de Rifles Motorizados soviética de primeira linha (c1985)

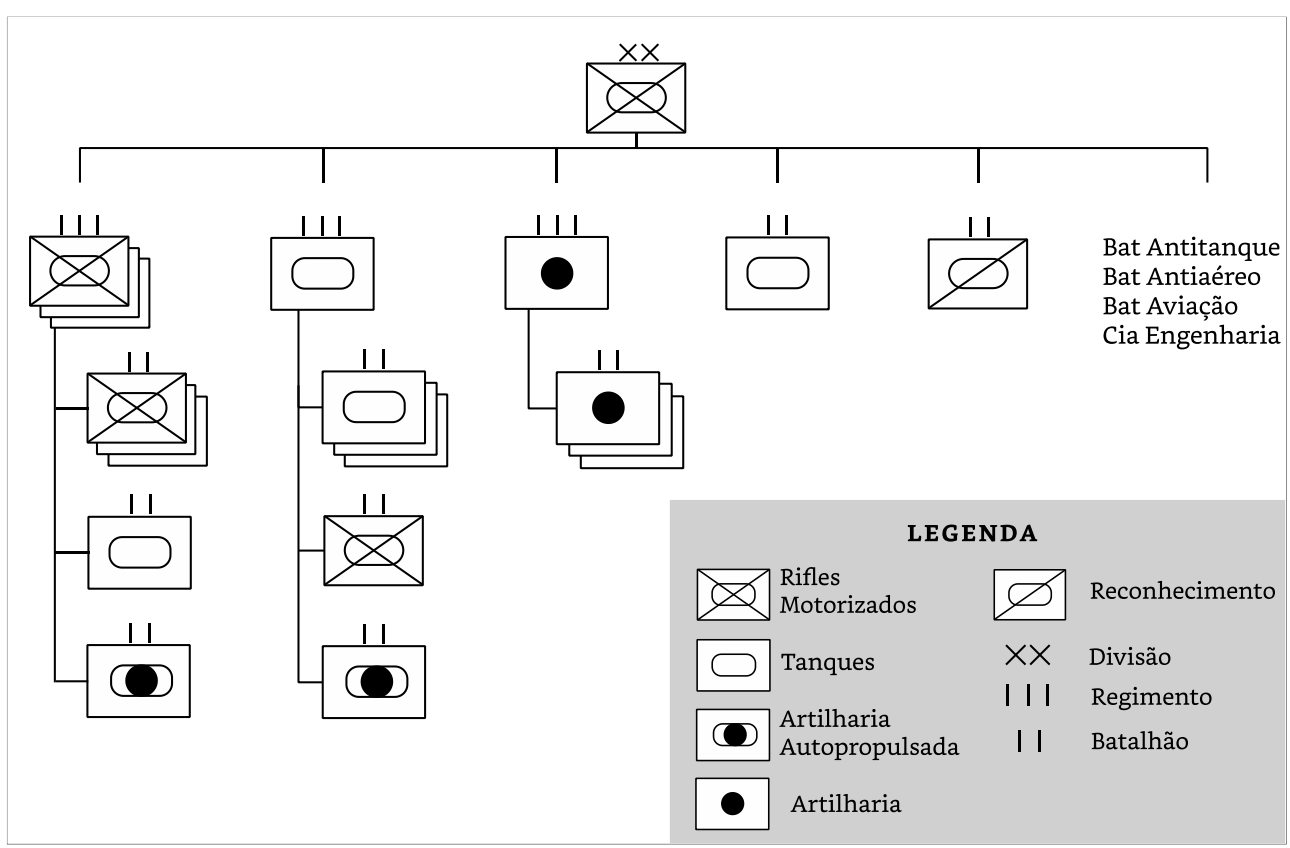

Fonte: Adaptado pelos autores de US Army 1991, p. 4-37.

A Divisão de Tanques (Figura 5) correspondia a 52 das 210 divisões que comporiam o Exército Soviético, com efetivo de 11 mil combatentes, 1,4 mil combatentes de infantaria, 450 tanques, 150 peças e lança-foguetes, 130 mísseis antitanque e 12 helicópteros cada uma (ISBY, 1988; US ARMY, 1991; VVAA, 2011).

Figura 5 - Divisão de Tanques soviética de primeira linha (c. 1985)

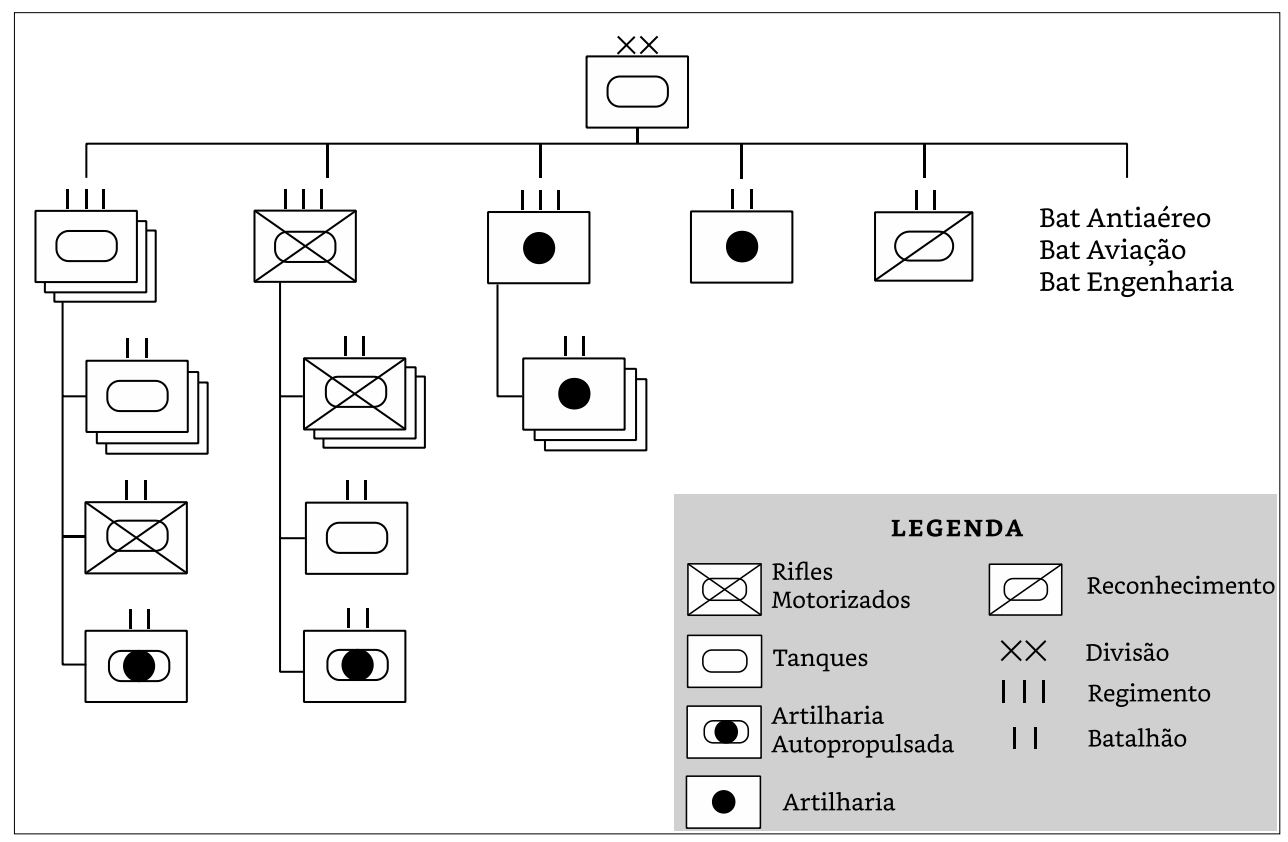

Fonte: Adaptado pelos autores a partir de US Army, 1991, p. 4-112. 
O refino nos detalhes do desenho organizacional das divisões se deu reproduzindo a mesma proporção de armas sucessivamente desde as menores até as maiores unidades. Era literalmente um exercício de 'mais do mesmo'.

A começar pela companhia de rifles motorizados, com três pelotões de infantaria (100 combatentes em 10 veículos blindados) e um pelotão de tanques (4 tanques). Tinha-se o batalhão e o regimento acrescentando a este último $3+$ 1 inicial diverso, 1 adicional de diferentes artilharias, e frações de 1, (designadas pelas reticências “...”), de especialidades como reconhecimento, antitanque, antiaérea e engenharia, entre outras. O batalhão tinha $(3+1+1+\ldots)$ companhias; o regimento tinha $(3+1+1+\ldots)$ batalhões. A companhia e o batalhão de tanques eram compostos apenas de tanques, mas a partir do regimento, as unidades de tanques espelhavam a mesma proporção reunindo 3 de tanques, 1 de rifles motorizados e 1 de artilharia com acréscimos (+...).

Na divisão havia o mesmo (3+1+1 regimentos $+\ldots)$. Havia um batalhão de tanques reforçado na divisão de rifles motorizados e um batalhão de artilharia lança-foguetes pesados na divisão de tanques. Seguia-se assim em cada exército numerado (3+1 divisões de infantaria e de tanques - nos de primeira linha, +1 divisão de artilharia - +...) e até a totalidade do Exército Soviético, com 150 divisões de rifles motorizados e 52 divisões de tanques, um número substancial de divisões de artilharia, além de batalhões, brigadas e "corpos" independentes $(+\ldots)$.

Assim organizadas, era de se esperar que a manobra e o combate fossem levados adiante pelos regimentos em escalões constituídos para que pudessem efetivamente ter e lutar com armas combinadas, pelo menos nas melhores divisões de primeira linha. Com isso, evitava-se a fragmentação das forças em unidades com escopo e escala inferiores aos necessários para fazê-lo. Entretanto, admitia-se o uso autônomo de certas unidades diante da ruptura, além de expedientes como passar a usar as peças de artilharia isoladamente para o tiro direto, como armamentos pesados, sobretudo para alcances curtos. De fato, havia diversas situações em que fazia mais sentido reverter ao todasas-armas, abrindo mão de parte da artilharia centralizada, fosse diante da necessidade de responder mais rapidamente do que era possível ou prudente 
diante dos limites nos sistemas de comunicação e na capacidade dos artilheiros, fosse quando se mostrasse conveniente mover a artilharia mais pesada para que pudesse atirar diretamente contra alvos mais difíceis ou resistentes.

O mesmo se aplicava às demais armas, que também teriam de continuar sendo capazes de apoiar o todas-as-armas quando não fosse possível ou expediente ter armas combinadas. Isso tornava o comando de um regimento, especialmente de rifles motorizados, particularmente desafiador: era preciso compor e recombinar oito armas e dezenas de armamentos em uma variedade considerável de modos de uso (COCKBURN, 1983; GLANTZ, 1991a; GLANTZ, 1991b; US ARMY, 1984).

As divisões soviéticas eram menores do que as da OTAN, e atuavam de forma mais concentrada e rígida. Era esperado que a sua retaguarda, e mesmo seus flancos, fossem protegidos pelo exército numerado ao qual estava integrada. Mesmo assim, sabia-se que as divisões seriam consumidas, provavelmente de forma expressiva, assim que entrassem em combate. Por isso seus desenho e treinamento enfatizariam manter seu foco numa única missão específica para lidar com a fragmentação no combate e baixas significativas (COCKBURN, 1983; GLANTZ, 1991a; GLANTZ, 1991b; US ARMY, 1984;). Essa rigidez em desenho e conduta se explicava por dois motivos distintos: o tático, dado pela necessidade de escolher o melhor desenho organizacional diante das capacidades do oponente, e o logístico, dado por restrições demográficas e industriais da sociedade soviética que afetariam sua capacidade de atender, em escopo e escala, às demandas por pessoal, armamentos e equipamentos das suas forças.

Havia uma excelente razão para se preocupar com o oponente. A capacidade de artilharia integrada da OTAN, e dos EUA, em particular, era avassaladora. Uma vez que soubesse de um alvo, fosse pelo relance fugidio de um helicóptero de reconhecimento, a projeção do ponto de origem do disparo de uma peça ou mesmo algo tão inusitado como um telefonema recebido de um cidadão alemão mais atento, era esperado que ele fosse prontamente despedaçado pela munição mais apropriada. Na prática, não havia defesa contra 
o fogo da artilharia, salvo se ela errasse o disparo ou o alvo se evadisse em tempo da posição na qual atirara (BAILEY, 2003; GUDMUNDSSON, 1993).

Portanto, era simplesmente razoável adotar uma formação compacta que permitisse aos soviéticos se moverem com a maior celeridade e discrição possiveis e contarem com alguma proteção na esteira de uma barragem que thes abrisse o caminho e reprimisse ao menos uma parte da artilharia da OTAN. Para que pudessem alcançar o oponente em condições de combate, parecia mesmo necessário partir em marcha acelerada por algum caminho imprevisto, em silêncio de rádio (e, portanto, sem contar com artilharia centralizada), até que atravessassem a zona de segurança entre seu ponto de partida e o de contato com o oponente (BAXTER, 1986).

Os soviéticos também sabiam das dificuldades adicionais que enfrentariam ao travarem uma guerra com tropas conscritas com um ou dois anos de treino e reservistas distantes até quinze anos de seu próprio serviço militar. Todos seriam chamados para preencher as divisões na hora da mobilização, movendo-se e combatendo num ritmo de 24 horas por dia, diante do furacão de fogo e da sucessão de emboscadas, refregas e batalhas que a OTAN colocaria em seu caminho (BAXTER, 1986). Por isso eles aceitavam e enfatizavam a incorporação de práticas invariáveis tanto na composição quanto no modo de agir das suas unidades. Sem a familiaridade e o automatismo conferidos pela constante repetição e pela mais rígida das disciplinas seria muito difícil seguir adiante. Sem regras e ordens impostas com firmeza não se alcançaria a fluência necessária para permitir atacar de forma sustentada com escalões sucessivos de diferentes tamanhos e qualificações (COCKBURN, 1983; ERICKSON, HANSEN; SCHNEIDER, 2019). Todavia, essa rigidez tinha seu preço: era extraordinariamente difícil recompor as armas depois que sofressem baixas, tão difícil quanto era compor, de forma oportunista, mesclas combatentes eficazes durante o desenrolar de um enfrentamento (ERICKSON, HANSEN; SCHNEIDER, 2019; GLANTZ, 1991).

Os tanques eram o elemento mais crítico de todo esse arranjo. Ao contrário das outras armas, que se podiam até certo ponto resguardar, os tanques tinham de estar necessariamente expostos em qualquer 
enfrentamento, e isso os tornava alvos prioritários do oponente. Dependia-se deles para liderar o ataque, apoiar a defesa, romper a linha e explorar a ruptura. Mais importante: era em torno deles que se articulava o todas-as-armas, e uma redução significativa em seu número implicava, primeiramente, a perda dessa capacidade. Por tudo isso era preciso ter um número generoso de tanques. E era justamente entre eles que se esperavam as perdas mais certas e numerosas (BAXTER, 1986; ERICKSON, HANSEN; SCHNEIDER, 2019; GLANTZ, 1991b; ISBY, 1988; ZALOGA, 1989). Isso levou a um esforço continuado, mas não particularmente bem-sucedido, de atualização técnica e aumento da produção de tanques de forma a viabilizar o incremento da dotação de cada unidade.

A meta de buscar superioridade convencional diante das forças da OTAN foi se tornando cada vez mais difícil de realizar entre meados dos 1960 e meados dos 1980. Havia duas dinâmicas significativas a restringi-la: a perspectiva de morbidade e declínio demográfico e a necessidade de capacidade industrial redundante para que se pudesse produzir as variedades e quantidades de armamentos necessários. A questão demográfica era inescapável e colocava diretamente em dúvida o funcionamento em escala do aparato de mobilização e prontidão das 210 divisões soviéticas. A questão industrial também, sobretudo porque a URSS entrava num período de estagnação econômica. Aceitar recompor as tropas com pessoal menos qualificado para que se mantivessem seus números punha em dúvida sua capacidade combatente. Ao mesmo tempo, ter todos os armamentos e equipamentos blindados mais atuais revelou-se além do alcance da capacidade industrial soviética (FRIEDMAN, 2007; HANSON, 2003).

Não havia o suficiente do melhor equipamento para todas as divisões, nem mesmo todas as divisões de primeira linha, que tinham prioridade em tudo. Isso explica por que decidiram combinar o regimento de veículos sobre lagartas e os dois regimentos sobre rodas nas Divisões de Rifles Motorizados, mesmo sabendo que isso levaria à perda de capacidade todo-terreno. Para que pudessem produzir mais veículos para a infantaria, os soviéticos acabaram decidindo manter grande parte da artilharia rebocada ao invés de montada em veículos blindados todo-terreno. Além disso, foram obrigados a conviver com os 
problemas decorrentes da impossibilidade de se padronizar os melhores armamentos de que dispunham, porque não havia escala suficiente na sua indústria e cada fábrica era especializada em determinados modelos, não podendo ser reconfigurada sem perdas inaceitáveis no volume global de produção (COCKBURN, 1983).

Quando a URSS chegou ao Afeganistão no final dos anos de 1970 não houve o que comemorar. Descobriu-se, com o passar dos anos, que muito do que se imaginava ter nos estoques em termos de equipamentos, partes de reposição, suprimentos e combustivel era só isso: fantasia. Além disso, havia problemas reais nas qualificações física e técnica do pessoal das reservas (COCKBURN, 1983; REESE, 2000). De fato, o Afeganistão foi um contraponto melancólico à campanha vitoriosa na Manchúria.

\subsection{As Divisões Blindada e Mecanizada dos EUA}

Os EUA chegariam ao desenho das suas divisões pesadas em c. 1985, depois de passarem por cinco grandes momentos de ajuste, amplamente documentados, que se podem grosseiramente demarcar pelas passagens dos governos Truman, Eisenhower, Kennedy, Nixon e Ford, e Reagan. Da mesma forma que havia acontecido na Segunda Guerra Mundial, os EUA seguiriam concebendo e implementando planos e ações a partir e em função de uma perspectiva organizacional. Tal perspectiva se expressava na busca da melhor adequação de meios a fins diante das mudanças nas suas circunstâncias e direções políticas (CSI, 1999; DUNNIGAN; HAWKINS, 2013; HAWKINS; CARAFINO, 1997; KEDZIOR, 2000; MACEDONIA, 2001; STEWART, 2010; WILSON 1998;). No primeiro momento, durante o governo Truman (1944-1953), as poucas divisões blindadas mantidas na ativa depois de 1946 foram submetidas a um processo contraditório, por vezes até esquizofrênico. Nele, divisões foram desativadas e reativadas, enviadas ao exterior e repatriadas e tiveram seus desenhos expandidos e reduzidos. A divisão pentômica que expressava o 'New Look do governo Eisenhower (1953-1961) seria uma reconfiguração de todas as divisões para lidar com o campo de batalha nuclear e assim contribuir com a perspectiva estratégica de "Retaliação Massiva” (KEDZIOR, 2000; WILSON 1998). 
Durante o governo Kennedy (1961-1963), houve uma reforma completa marcada pela percepção de que, para se ter capacidade de resposta flexível diante dos soviéticos, se fariam necessárias forças capazes de travar uma guerra sem armamentos nucleares. Isso levou a um novo e mais moderno desenho, as divisões ROAD, Reorganization Objective Army Divisions. Definiu-se uma base divisional comum para todas as divisões, que teriam três brigadas cada, com imensa flexibilidade na sua composição. Os batalhões de cada divisão seriam definidos para responder a uma contingência determinada e em função das suas circunstâncias e demandas específicas (KEDZIOR, 2000; WILSON 1998).

A evidente escalada em armamentos e tropas da URSS em meados dos anos de 1960 preocupava sucessivos governos estadunidenses. No governo Johnson (1963-1969), pouco se pode fazer diante do acirramento da Guerra Fria e do juízo de inferioridade técnica e numérica estadunidense diante do melhor soviético na Alemanha. Além disso, durante a guerra no Vietnã, os EUA tiveram de lidar com os efeitos organizacionais e combatentes de terem formado suas tropas a partir do alistamento obrigatório. Foram os governos Nixon (1969-1974) e Ford (1974-1977) que tiveram de lidar com essa situação, a começar pela reconfiguração necessária para que adotassem um exército todo voluntário. Com isso acumularam-se diversos resultados estruturantes, dois dos quais de especial relevância para o desenho organizacional das divisões pesadas.

A criação do Comando de Doutrina e Treinamento, TRAining and DOctrine Command - TRADOC, em 1973, apontava para uma profissionalização intensa do exército, inicialmente ao garantir contratos mínimos de sete e usuais de catorze anos aos soldados. O TRADOC promovia uma integração sistêmica entre as atividades de ensino, preparo e exercício de pessoal em todos os seus aspectos, em substituição às soluções idiossincráticas de cada arma e quadro. Assim como teste e avaliação haviam sido críticos para garantir a confiabilidade do material na Segunda Guerra Mundial, o processo de ensino, preparo, treinamento e teste de desempenho do TRADOC foi crítico para garantir a confiabilidade de pessoal (ROMJUE, 1985; ROTTMAN, 1988).

Além disso, houve uma atualização no entendimento das condições de contorno que realmente viriam a reger uma guerra na Europa e como isso 
impactaria o modo de combater contra os soviéticos. Esse entendimento, materializado notadamente no manual de operações FM 100-5 de 1976, dava solução de desenho integrada diante de três questões: o desempenho dos armamentos já havia avançado para além do auge do estado da arte; a Alemanha Ocidental vivia um processo de intensa urbanização; e a URSS provavelmente só teria êxito numa guerra europeia se seguisse um cenário específico (HERBERT, 1988; US ARMY, 1976; WILSON, 1998).

Cada tipo de armamento dos EUA era capaz de elevada precisão de tiro, de dia ou à noite, em todas as condições climáticas, com capacidade de penetração e destruição suficiente para superar quaisquer blindagens ou medidas de proteção existentes ou que viessem a ser desenvolvidas pelos soviéticos nos dez anos seguintes. Somava-se a isso o progresso em munições guiadas, tanto para o tiro direto, como mísseis antitanque, quanto para o tiro indireto, como no caso das munições ditas inteligentes. Diante do que se aprendera com a Guerra Árabe-Israelense de 1973 e do alargamento no estado da arte no que tocava o desempenho dos armamentos, ficava claro que a conduta que ainda se praticava com base na experiência da Segunda Guerra Mundial precisava ser substituída por algo inteiramente diferente.

Em segundo lugar, a urbanização da Alemanha Ocidental havia transformado o entorno e os acessos às suas estradas e a vizinhança estendida de suas cidades e vilas. Em lugar de terreno aberto ou florestas, havia grandes zonas de concreto armado, com subsolos para garagens e redes de esgoto em cada lado de estreitas ruas de duas pistas. Havia também obras públicas em concreto ligando as zonas urbanas (ou suburbanas) e mais construções, também em concreto, em locais aprazíveis com largas vistas, como cruzamentos e elevações. Mesmo que feitas em ruínas, essas obras e prédios dariam proteção contra quase todos os armamentos soviéticos, à exceção dos mais pesados.

Finalmente, em terceiro lugar, excetuado um ataque surpresa, ficava claro que toda esperança de sucesso dos soviéticos dependeria da sua capacidade de articular ondas sucessivas de atacantes que conseguissem exaurir as defesas da OTAN. ISso corresponderia ao provável modo de empenho dos exércitos 
numerados desde suas bases na URSS e na Europa Oriental, e de divisões e regimentos dos seus exércitos numerados.

A nova formulação da conduta que emergiria começou por abandonar a ideia da batalha limitada à linha de frente. Em seu lugar, articulou-se uma forma de combate que travava três batalhas simultaneamente: uma batalha de retaguarda, contra a infiltração ou exploração da ruptura pelo oponente; uma batalha de linha de frente, para forçar o desgaste do oponente e impedir uma ruptura, obrigando-o a se reorganizar ou a esperar o próximo escalão de ataque; e uma batalha profunda, na qual se atacavam os escalões adicionais do oponente, para impedir que produzissem um efeito cumulativo.

Essa reformulação, embora nascida na OTAN, implicava a ideia de integração das forças estadunidenses em todos os seus meios convencionais, e veio a se materializar na doutrina chamada de Batalha AeroTerrestre. A incorporação do Aero se daria a partir de duas questões, a primeira das quais já dada como certa: o imenso impacto do helicóptero, não apenas como sensor de reconhecimento, mas também como plataforma de fogos e de transporte de pessoal, armamento e suprimentos. A outra, ainda potencial, era a expectativa em relação ao que a Força Aérea pudesse vir a fazer com suas aeronaves antitanque, munições customizadas e munições inteligentes.

Enquanto isso, o Exército dos EUA tentava alinhar as suas capacidades a missões que satisfizessem ao grande número de cenários para o uso da força definidos pelo governo Carter (1977-1981). Como consequência desse processo, as divisões pesadas ficaram em segundo plano. Havia divisões blindadas e mecanizadas, mas nem seu armamento, nem sua conduta atendiam ao disposto no Manual de Operações FM 100-5 de 1976.

Diante do fortalecimento soviético, o governo Reagan (1981-1989) tomou a decisão política de aumentar substancialmente o orçamento estadunidense de defesa. Como consequência, duplicou-se o número de divisões pesadas a serem enviadas à Europa, e seus depósitos de armamentos e estoques de suprimentos foram expandidos de acordo. As forças pesadas dos EUA foram redesenhadas a partir da proposta do "Exército de Excelência" e sob o mote de "lutar 
assoberbado pelos números e ainda assim vencer" para produzir um arranjo capaz de responder a um ataque soviético na Europa.

No novo arranjo, havia três corpos-de-exército pesados permanentemente compostos. Dois deles, com quatro divisões, uma brigada avançada de uma divisão e um regimento de cavalaria blindada, ficariam na Europa. O outro corpo-de-exército, com o restante da divisão, cinco outras divisões e um regimento de cavalaria blindada, ficaria nos EUA e seu pessoal seria transportado pelo ar até a Europa e usaria equipamentos lá estocados. De acordo com esse desenho, teriam quatro companhias por batalhão (aumentando seu tamanho em 1/3), e a artilharia pesada, mísseis antiaéreos e helicópteros poderiam ser deslocados para o comando dos corpos-de-exército (CSI, 1999; DAVIES et al. 2019; DUNNIGAN; MACEDONIA, 2001; SKINNER, 1989; ROMJUE, 1997; WILSON, 1998).

Chegou-se assim às Divisões Blindada e Mecanizada de 1983 (Figura 6), cada uma com 17 mil combatentes, formalmente com três comandos configuráveis de brigada e partilhando de uma mesma base divisional. Cada divisão tinha nessa base divisional comum um batalhão de cavalaria blindada especializado em reconhecimento e retardamento (18+ tanques, 100+ combatentes de infantaria, 6 peças, 40+ mísseis antitanque, 10+ helicópteros), 72 peças e lança-foguetes, fortes contingentes de engenharia e antiaérea e ainda 50 helicópteros. Estes últimos eram ditos uma brigada de aviação, mas de fato, desde o primeiro momento, revelaram-se uma brigada, a quarta, como as demais. Haveria 4 batalhões mecanizados e 6 batalhões blindados na Divisão Blindada (somando 2,5 mil ou mais combatentes de infantaria, 450 tanques, 400+ mísseis antitanque), e 6 batalhões mecanizados e 4 batalhões blindados na Divisão Mecanizada (somando 4 mil ou mais combatentes de infantaria, 350 tanques, 500+ mísseis antitanque) (CSI, 1999; ROMJUE, 1985; ROMJUE, 1997; WILSON, 1998; KEDZIOR, 2000; DAVIES et al., 2019). 
Figura 6 - Divisões Blindada e Mecanizada estadunidenses (c1985)

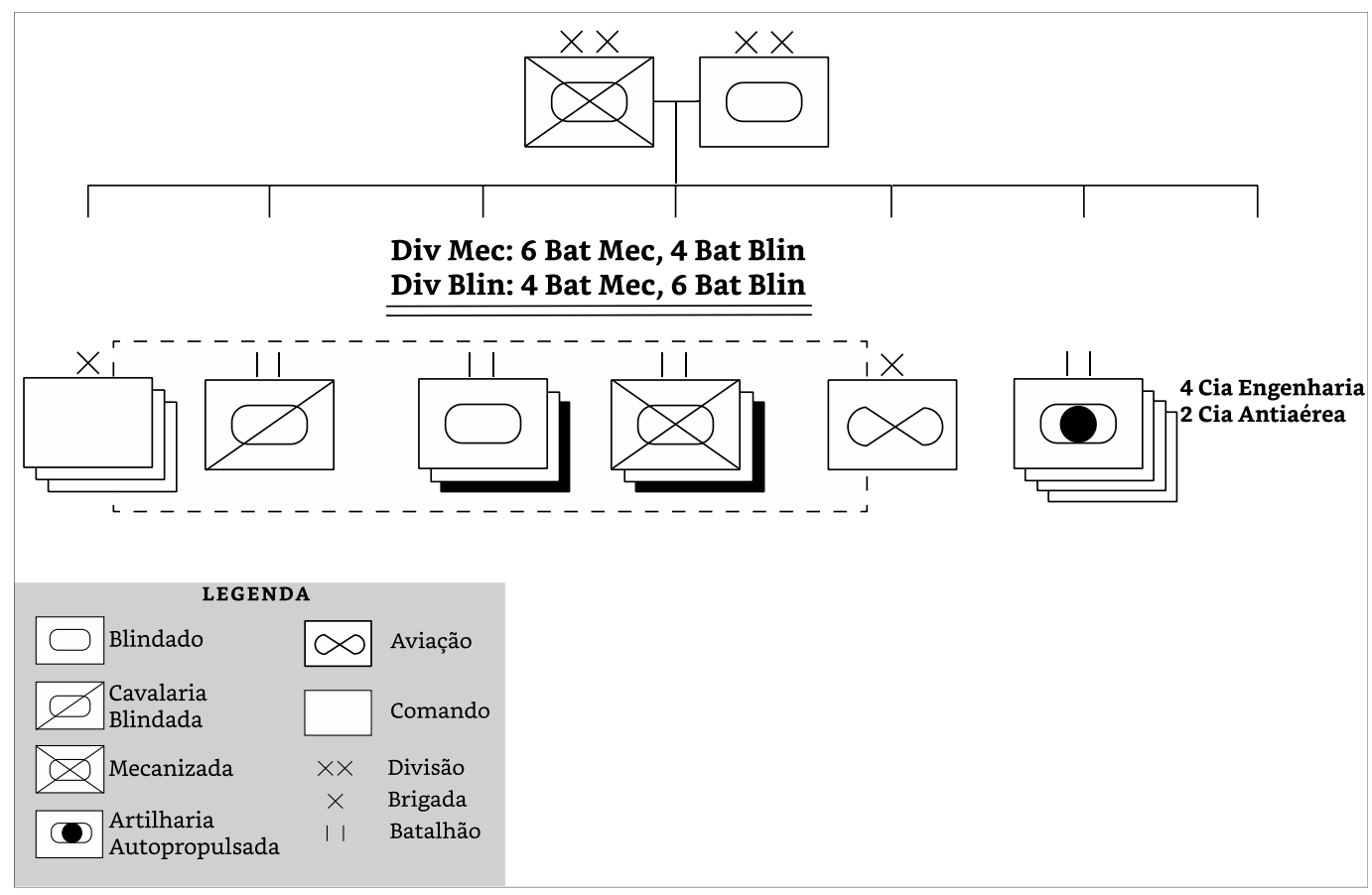

Fonte: Adaptado pelos autores a partir de CSI, 1999, p. 44.

Mísseis antiaéreos, artilharia pesada e helicópteros passariam ao comando do corpo-de-exército. Na Alemanha, o V Corpo, com duas divisões, teria 162 peças e lança-foguetes e 100 helicópteros e ainda subordinaria um regimento de cavalaria blindada (1,5 mil combatentes de infantaria, 180 tanques, 50 peças, 60 helicópteros, 100+ mísseis antitanque), representando o auge das armas combinadas dos EUA, capaz de qualquer tarefa. O VII Corpo, também com duas divisões, teria 243 peças e lança-foguetes e 100 helicópteros, e subordinaria diretamente uma brigada mecanizada (1,2 mil combatentes de infantaria, 70 tanques, 48 peças, 50+ mísseis antitanque). O III Corpo, nos EUA, a ser enviado 'em 10 dias', teria cinco divisões, duas brigadas mecanizadas, um regimento de cavalaria blindada, 243 peças e mais que o dobro de helicópteros dos dois corpos a avante. Tudo isso esperava apenas a chegada de pessoal aos depósitos de equipamentos completos e prontos na Europa. Incidentalmente, as tropas eram treinadas na vinda à Europa, reequipamento e disposição em campo para manobras regularmente, a cada ano em diferentes estações (STEWART, 2010; DAVIES et al., 2019). 
Diante disso, se poderia argumentar que o projeto de força terrestre dos EUA teria deslocado o ponto ótimo de enquadramento da divisão para o corpode-exército. Isso é parcialmente verdadeiro, especialmente em relação a mísseis antiaéreos empregados no rumo de um arranjo unificado de defesa aérea da OTAN, cuja análise excederia o escopo deste artigo. Mas as divisões continuaram sendo o centro das armas combinadas. Era nelas que se concentravam de maneira quase completa as tropas de infantaria e blindadas, articuladas de fato em quatro brigadas polivalentes, capazes de configurações customizadas para lutar $360^{\circ}, 24 / 7$, dia e noite, em qualquer condição climática.

Um último ponto é que o volume do estoque e a capacidade de distribuição de suprimentos dos EUA na Europa mais do que dobraram entre 1981 e 1985. Isso abrangia munições de todos os tipos, combustível com aumento da redundância e da capacidade avançada de reabastecimento e todos os arranjos necessários para a sua proteção. Também abrangia uma cadeia de distribuição capaz de armazenar seus estoques já nas configurações de cargas para transporte por caminhões fora-de-estrada e helicópteros e de alcançar unidades empenhadas no combate. Esse panorama de aumento da capacidade e resiliência dos EUA permite considerar que "lutar assoberbado pelos números e ainda assim vencer" fosse mais que mera locução retórica.

A Guerra do Golfo de 1990-1991 revelou em que grau a Batalha AeroTerrestre realmente representava o auge do estado da arte em conduta e desenho. Ela permitia a segmentação dos esforços e da força do oponente e a fluência no uso constante e otimizado das armas combinadas em toda a profundidade do dispositivo oponente. É oportuno chamar a atenção para quanto dessa capacidade é mesmo de enquadramento, preparo e fruto do que se pode ter e fazer em função de um desenho organizacional eficaz. No Iraque, os EUA tinham vantagem material em tudo, mas nem eram invulneráveis, nem possuíam armamentos que os dispensassem de combater (CORDESMAN; WAGNER, 1996; DUNNIGAN; MACEDONIA, 2001).

De fato, como os soviéticos contra os japoneses na Manchúria em 1945, os estadunidenses estavam numa outra classe. No entanto, muito da discussão de como venceram admite a consideração de que teriam vencido mesmo que os 
armamentos tivessem sido trocados. Isso porque as suas práticas de armas combinadas permitiriam explorar muito melhor os armamentos mais antigos do que seus oponentes poderiam fazer com os armamentos mais avançados. E isso também não deve ser tomado como mera retórica.

\section{Conclusão}

O satélite, a televisão e o computador transformaram profundamente o mundo a partir do final dos anos 1940. Apesar disso, quando se comparam os desenhos das divisões pesadas da URSS e dos EUA em 1945 e c. 1985, ficam claras a continuidade da sua concepção e a convergência nos juízos de cada superpotência, fosse em relação à centralidade das armas combinadas para projetos de força terrestre; à importância da escala para se permitir desdobramento da força no espaço e sua duração no tempo; e à identidade das armas em relação a capacidades combatentes e variedade de equipamentos. Tudo isso se materializava num ponto ótimo de escala e escopo: a divisão (de 10 mil a 20 mil combatentes). Isso se deu mesmo diante do contexto e situação de cada uma e das restrições que enfrentavam para elaborar e pôr em prática seus respectivos projetos de força.

E nos últimos 30 anos? O que se pode dizer dessa passagem diante do que se argumentou a respeito de ótimos de escala e escopo para poder combater com armas combinadas? Afinal, entre 1990 e 2021 se observou o deslocamento do cerne do projeto de força terrestre para a brigada (de 3 mil a 5 mil combatentes). Entretanto, não parece possível argumentar que esse caminho tenha resultado num alargamento do estado da arte bélico. Ao contrário, se verá que desde início da década de 2010, a Rússia vem retomando o desenho divisional a despeito das suas significativas restrições de recursos e pessoal, e, além disso, que perspectivas por vezes contraditórias em torno de como se deveria desenhar o projeto de força estadunidense não permitem ainda compreender como se daria a próxima reorganização nas suas forças.

Uma breve recapitulação e comparação das divisões da URSS e dos EUA em 1945 e c. 1985 evidencia a continuidade em concepção e permite indicar como 
diferenças nas suas escolhas se deram em função dos seus contextos e situações particulares.

O desenho das divisões soviéticas de c. 1985 seguiu o mesmo enquadramento e proporção de armas dos corpos de 1945: 3 + 1 + 1 (de artilharia) e (...) frações de 1 para tudo, 'mais do mesmo', buscando assegurar que se teria o necessário para agir com armas combinadas de maneira regular e previsível (Figura 7 e Figura 8).

Figura 7 - Comparação do Corpo de Tanques (1942-1945) e da Divisão de Tanques (c. 1985) soviéticas.

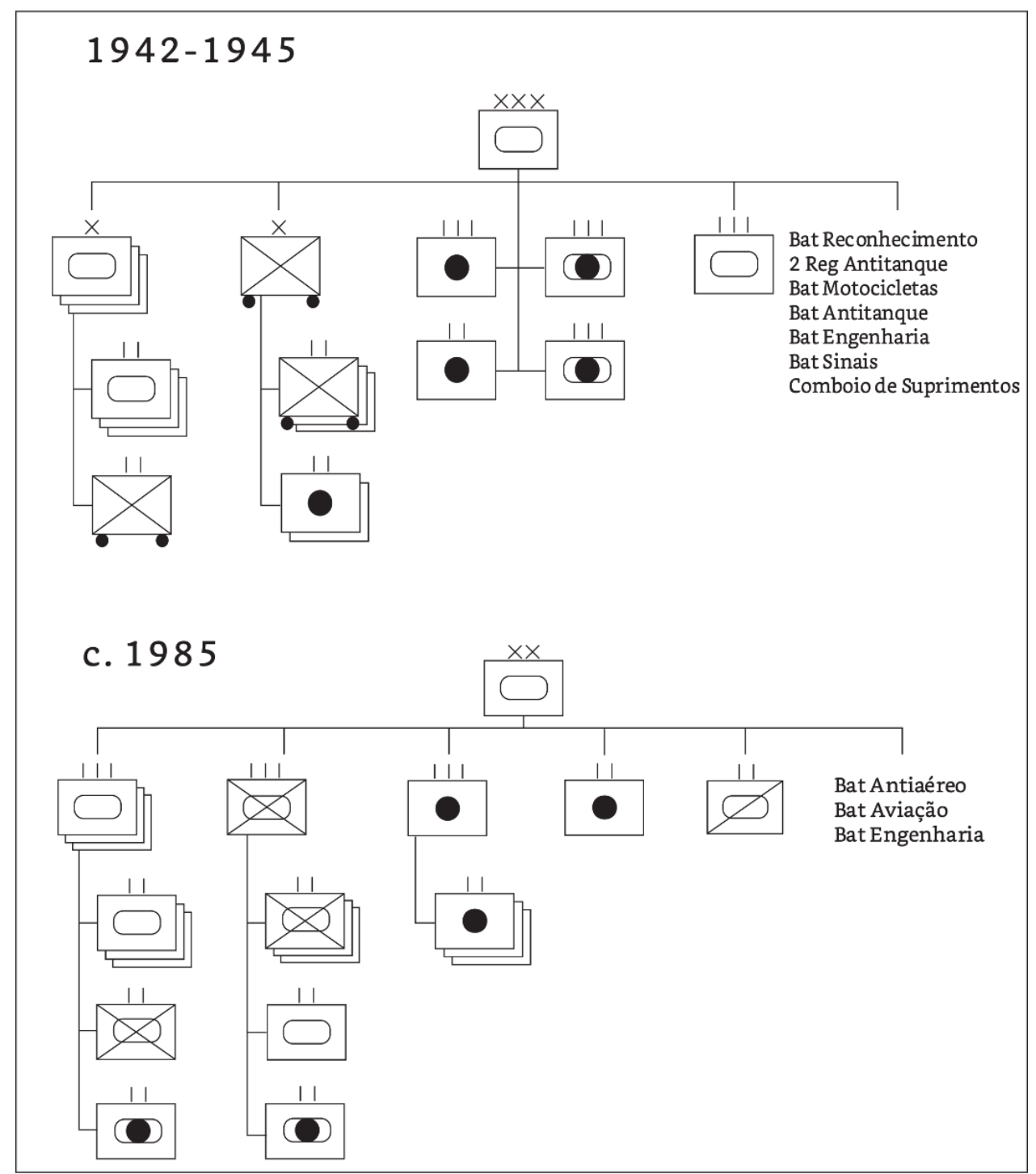

Fonte: Adaptado pelos autores de Dunnigan, 1977, p. 120 e US Army, 1991, p. 4-112. 
Figura 8 - Comparação do Corpo Mecanizado (1942-1945) e da Divisão de Rifles Motorizados (c1985) soviéticas.

\section{$1942-1945$}

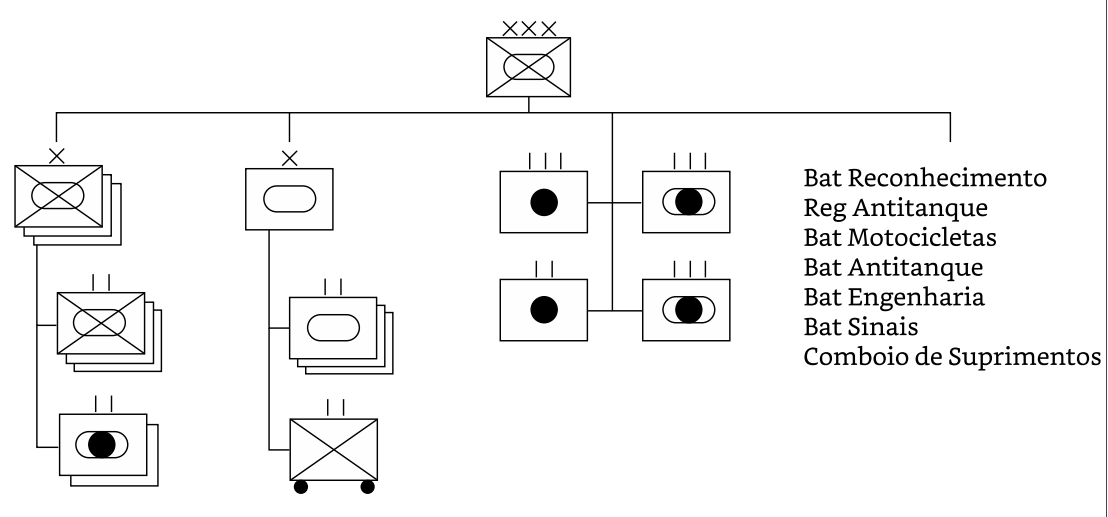

\section{c. 1985}

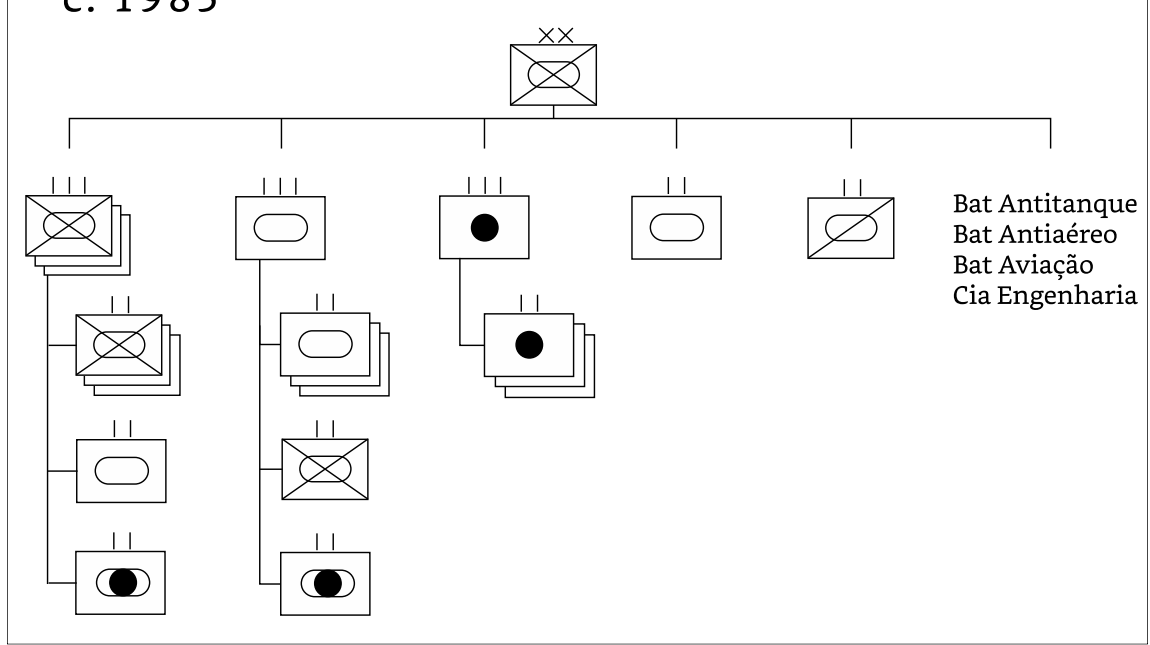

Fonte: Adaptado pelos autores de Dunnigan, 1977, p. 121 e US Army, 1991, p. 4-37.

No caso soviético, a ausência de artilharia centralizada e de suprimento motorizado na Segunda Guerra Mundial foram contingências inicialmente sanadas a partir de ganhos de desempenho técnico, permitindo assim o desenho das suas forças com a ambição de praticar armas combinadas no estado da arte. Apesar disso, as divisões soviéticas da Guerra Fria tiveram que lidar com restrições de ordem material e de pessoal que se acentuariam ao longo dos anos de 1970 e 1980. Por conta delas, não foi possível continuar atendendo às demandas de cada arma por veículos blindados, e teve-se de aceitar essas restrições e seus efeitos no combate, como a perda de capacidade todo-terreno de grande parte de sua infantaria motorizada e artilharia. Uma outra questão era que a maior parte da tropa provinha do serviço militar obrigatório, e isso limitou 
o quanto era possível capacitá-la. Como solução, escolheram adotar condutas e práticas combatentes rígidas, invariáveis, e compor as tropas em escalões de grandes dimensões que deveriam lutar numa única direção em cada momento, também tendo de aceitar os efeitos disso no combate, como reverter mais uma vez ao todas-as-armas.

O desenho das divisões estadunidenses em c. 1985 também seguiu o mesmo enquadramento que o de 1945. A partir dele se buscou assegurar a formação de capacidades e a disponibilidade de equipamento para que pudessem compor mesclas combatentes de armas combinadas de maneira flexível e oportunista (Figura 9).

Figura 9 - Comparação da Divisão Blindada (1943-1945) e das Divisões Blindada e Mecanizada (c1985) estadunidenses

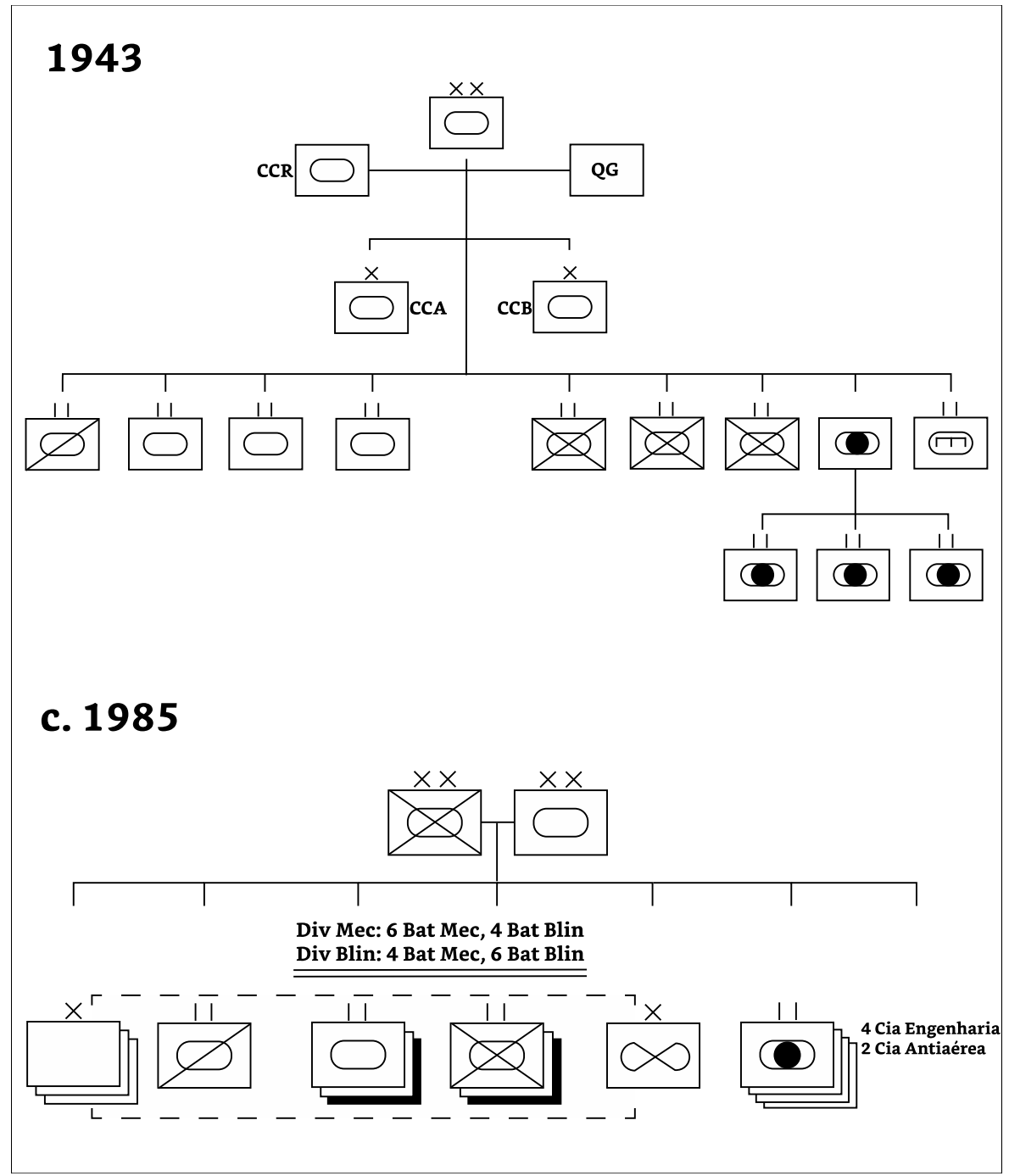

Fonte: Adaptado pelos autores a partir de Zaloga, 2004, p. 13 e de CSI, 1999, p. 44. 
No caso estadunidense, a disponibilidade de pessoal capacitado, armamentos, equipamentos e suprimentos levou a um alargamento no estado da arte de armas combinadas. Na Segunda Guerra Mundial, os EUA puderam ter tropas todo-terreno com seus meias-lagartas e artilharia autopropulsada e vieram a dispor de artilharia integrada em toda a força. Na Guerra Fria, após um período inicial em que se viram superados pelos soviéticos, os EUA reconfiguraram as suas forças a partir da profissionalização da tropa e da unificação da sua doutrina combatente no TRADOC. A sua escolha foi por traduzir ganhos de desempenho técnico em ampliação de capacidade combatente, levando a uma divisão de grandes dimensões pautada por composição e conduta flexíveis, capaz de lutar em 360, 24/7, todo-clima, todo-terreno. Com isso, puderam fazer do helicóptero uma nova arma combatente montada, ao contrário dos soviéticos, que só conseguiram incorporá-lo como mais um armamento, e dispor de estoques e cadeias de distribuição na Europa que thes permitiam compor unidades combatentes pelo simples transporte do pessoal desde os EUA.

Tanto no caso soviético quanto no estadunidense, percebe-se que o que se tinha em c. 1985 atualizava o que se ambicionara em 1945. Não por inércia, mas porque se entendia que a solução e o enquadramento para a questão das divisões pesadas haviam permanecido os mesmos. Ambas as superpotências tinham um mesmo conjunto de expectativas em termos de escopo e escala diante de um estado da arte partilhado. A continuidade do desenho de suas divisões expressava um juízo comum quanto à estabilidade das armas, à centralidade das armas combinadas para o projeto de força e ainda quanto às dimensões e capacidades necessárias para se porem no espaço e no tempo de forma a produzir vantagem combatente. É desse modo que se pode explicar a manutenção da divisão como cerne de seus projetos de força.

Mesmo assim, atualmente há diversas tentativas de deslocar o cerne do projeto de força terrestre para a brigada. Há diversas razões que podem explicar decisões nesse sentido, cuja longevidade já alcança 30 anos. Inicialmente, havia a viva expectativa de que se poderiam reproduzir no mundo bélico os ganhos em escala e escopo que a digitalização produziu no mundo civil. Por isso, a escolha 
da brigada não se deu diante da certeza de perda de capacidade combatente. Esperava-se poder fazer o mesmo em termos de armas combinadas, só que gastando menos (DUNNIGAN; MACEDONIA, 2001).

Desde então, vinha parecendo que a brigada se mostraria suficiente. Os conflitos armados durante esse período não envolveram sociedades capazes de se enfrentar com armas combinadas, não tiveram grandes dimensões, nem duraram por muito tempo. E assim, não foi possível observar qualquer problema maior com as brigadas até que a Rússia tivesse decidido, por volta de 2010, retornar à divisão.

A sua escolha pelas brigadas se dera em 1992, a partir da realidade de que se havia material de sobra (herdado da URSS), havia pessoal qualificado de menos. Isso levou a diversas composições de conscritos, contratados e profissionais, todas insatisfatórias. Além disso, a escala de efetivos das brigadas não guardava qualquer compatibilidade com o escopo combatente desejado, e foi ficando claro o quão difícil seria dar sentido de prontidão e disponibilidade à força dali resultante. Descobriu-se que as únicas tropas competentes eram as remanescentes da estrutura divisional soviética e foi com essas que se pôde obter sucesso nas guerras travadas nas décadas de 1990, 2000 e 2010. Por conta disso, algumas divisões foram sendo preservadas e outras reativadas, até que se acabou retomando o desenho divisional como cerne do projeto de força russo (GLANTZ, 2010; GALEOTTI, 2017; RENZ, 2018).

A restauração do 10 Exército de Tanques de Guardas (1o ETG) em 2014 é o exemplar mais consequente desse retorno à divisão. Uma análise mais detalhada dessa unidade extrapolaria o escopo deste artigo. Entretanto, é suficiente apontar que o desenho do 10 ETG e das demais unidades que o seguiriam corresponde a uma divisão pesada no estado da arte das armas combinadas. Tem ao redor de 20 mil combatentes com ao menos seis regimentos, artilharia centralizada, comboio de suprimentos e unidades de helicópteros, drones, ciberguerra e armamentos eletromagnéticos. Poderia lutar $360^{\circ}$ e sustentar a luta 24/7, todoclima, todo-terreno (BRONK, 2017; CRANE, OLIKER; NICHOPORUK, 2019; IISS, 2016; SUTYAGIN). 
Um outro efeito importante do retorno de uma divisão pesada à cena foi a reconfiguração do equilíbrio de forças na Europa, que vinha sendo medido em termos de brigadas e do que elas podiam fazer. Tentar barrar uma unidade como o 1o ETG apenas agremiando brigadas significaria lutar em considerável desvantagem. Na prática, isso significava que não se teria como responder a um gesto militar russo que empregasse uma ou mais unidades como o 10 ETG com expectativa razoável de sucesso (MARTYANOV, 2018; FLANAGAN et al., 2019).

Nos EUA, os limites da brigada se colocaram por razões e de maneiras distintas, em decorrência de um impasse entre três perspectivas de projetos de força por vezes contraditórias entre si. Todas elas guardam, em comum, a expectativa de que a digitalização eliminaria a divisão e o corpo-de-exército (MACGREGOR, 1997) e levaria a um guerrear centrado-em-rede que se travaria integrando armas e brigadas (MANDELES, 2005).

A primeira perspectiva é a expedicionária, a partir da qual se devia trocar tanques e veículos sobre lagartas por carros blindados e veículos sobre rodas para poder dispor de brigadas médias e de infantaria leve. Essas brigadas podiam ser configuradas em escopo de armas e escala de efetivo para cada missão e movidas pelo ar desde os EUA (DUNNIGAN; MACEDONIA, 2001; STEWART, 2010). A segunda envolve usar divisões não mais como instância de escala e escopo combatente, mas sim como residência administrativa para brigadas de um ou mais tipos. Isso significa que elas podiam abrigar brigadas pesadas, médias, de variedades de infantaria, aviação, suporte e outras para atender a diferentes cenários (STEWART, 2010; BROWN, 2011; CANCIAN, 2020). Uma terceira e mais difusa perspectiva decorre do aprendizado da longa "guerra global contra o terrorismo". Esta foi marcada por missões de segurança, contra-terror e contrainsurgência e pelo uso preponderante das tropas de infantaria para guarda, patrulha, incursões e atividades cívico-militares. Do ponto de vista dessa realidade viva e inculcada, o escopo de armas combinadas era pouco relevante e a escala da divisão era mesmo inapropriada (MACGREGOR, 2003; STEWART, 2010).

O efeito disruptivo do convívio dessas diferentes perspectivas vem sendo agravado por sucessivas revisões no orçamento do Exército dos EUA desde 
meados dos anos 2000 (CANCIAN, 2020). Essa situação tem praticamente imobilizado o processo de modernização de competências em armas combinadas e ameaçado a integridade do projeto de força terrestre estadunidense (BROWN, 2011; MARTYANOV, 2018; MCCONVILLE, 2021). Entretanto, agora em 2021, tem-se o borbulhar de mais uma perspectiva, distinta das demais, que reconhece a necessidade de se retomar armas combinadas com fluência. Em termos de escopo, haveria armas combinadas expandidas por múltiplos domínios, ciberguerra, drones e uma variedade de possibilidades outras que não estritamente de guerra. Em termos de escala, seria necessária a capacidade de lidar com oponentes dispondo de forças do porte do 10 ETG. Isso traz, ao primeiro plano, mais uma vez, a questão do desenho organizacional da força (MCCONVILLE, 2021).

Observam-se, portanto, evidências no sentido de apoiar a retomada da divisão e a continuidade da relevância da agenda de pesquisa que estuda as questões que se apresentam em função disso, em especial diante da ascensão dos drones e de outras formas de guerrear. Esse resultado não chega a ser surpreendente. Uma vez que se encaminham as questões de escala e escopo, percebem-se os limites da brigada, e torna-se necessário reconsiderar, mais uma vez, a utilidade do desenho da divisão como cerne do projeto de força terrestre.

\section{Referências}

ALLEN, Matthew. Military helicopter doctrines of the major powers, 1945-1992. Westport: Greenwood Press, 1993.

ATKINSON, Rick. An army at dawn: the war in North Africa, 1942-1943. New York: Henry Holt and Co., 2002.

BAILEY, Jonathan B. A. Field artillery and firepower. Annapolis: US Naval Institute Press, 2003.

BAXTER, William P. Soviet airland battle tactics. Novato: Presidio Pr., 1986. 
BELLAMY, Chris. Absolute war: Soviet Russia in the Second World War. Vancouver: Vintage, 2008.

BELLAMY, Chris. The evolution of modern land warfare: theory and practice. London: Routledge, 2015.

BOYNE, Walter J. How the helicopter changed modern warfare. Gretna: Pelican Publishing, 2011.

BROWN, John Sloan. Kevlar legions: the transformation of the U.S. Army, 19892005. Washington: Center of Military History, 2011.

CANCIAN, Mark F. US military forces in FY 2021: army. Washington: CSIS, 2020.

COAKLEY, Robert W; LEIGHTON, Richard M. Global logistics and strategy, 19431945. Washington: Office of the Chief of Military History: United States Army, 1968.

COCKBURN, Andrew. The threat: inside the Soviet military machine. London: Random House, 1983.

CORDESMAN, Anthony H; WAGNER, Abraham. The lessons of modern war: the Gulf War. Boulder: Westview, 1996.

CRANE, Keith; OLIKER, Olga; NICHIPORUK, Brian. Trends in Russia's armed forces: an overview of budgets and capabilities. Santa Monica: RAND, 2019.

CSI. Combat Studies Institute. Sixty years of reorganizing for combat: a historical trend analysis. Fort Leavenworth: Combat Studies Institute, 1999.

DAVIES, R. Mark et al. USA 1980s TO\&Es: v 2.7. Ocean Isle Beach: Fire and Fury Games, 2019.

DEIGHTON, Len. Blitzkrieg: from the rise of Hitler to the fall of Dunkirk. [S.l.]: Castle, 2000.

DELBRÜCK, Hans. The dawn of modern warfare: history of the art of war. Lincoln: University of Nebraska Press, 1990. v. 1.

DUNNIGAN, James F. Organization of Soviet Ground Forces. In: STAFF, S.; STAFF, T. (eds.). The war in the East. New York: SPI, 1977. p. 105-125.

DUNNIGAN, James F.; MACEDONIA, Raymond M. Getting it right: American military reforms after Vietnam to the Gulf War and beyond. 2. ed. New York: William Morrow \& Co, 2001. 
DUPUY, Trevor Nevitt. The evolution of weapons and warfare. Boston: Da Capo Press., 1990.

EDGERTON, David. Britain's war machine: weapons, resources and experts in the Second World War. London: Allen Lane, 2011.

ELLIS, John. The World War II databook: the essential facts and figures for all the combatants. London: Aurum Press, 1993.

ENGLISH, John A.; GUDMUNDSSON, Bruce I. On infantry. 2. ed. Westport: Praeger, 1994.

ERICKSON, John; HANSEN, Lynn; SCHNEIDER, William P. Soviet ground forces: an operational assessment. London: Routledge, 2019.

EVANS, Michael. General Monash's orchestra: reaffirming combined arms warfare. In: EVANS, Michael; RYAN, Alan. From Breitenfeld to Baghdad: perspectives on combined arms warfare. Duntroon: Land Warfare Studies Centre, 2003. p. 1-26.

FLANAGAN, Stephen J. et al. Deterring Russian aggression in the Baltic States through resilience and resistance. Santa Monica: Rand, 2019.

FRIEDMAN, Norman. The Fifty-Year War: conflict and strategy in the Cold War. Annapolis: Naval Institute Press, 2007.

GALEOTTI, Mark. The modern Russian army 1992-2016. Oxford: Osprey, 2017.

GILLIE, Mildred Hanson. Forging the thunderbolt: a history of the development of the armored force. Washington: Military Service Publishing, 1947.

GLANTZ, David M. Soviet Force Structure in an Era of Reform. The Journal of Soviet Military Studies, [S.l.], v. 2, n. 3, p. 361-93, 1989.

GLANTZ, David M. Soviet military operational art: in pursuit of deep battle. London: Frank Cass, 1991a.

GLANTZ, David M. The Soviet conduct of tactical maneuver: spearhead of the offensive. London: Routledge, 1991b.

GLANTZ, David M. The military strategy of the Soviet Union: a history. London: Routledge, 2001.

GLANTZ, David M. The Soviet strategic offensive in Manchuria, 1945: August Storm. London: Routledge, 2003. 
GLANTZ, David M. The Development of the Soviet and Russian Armies in Context, 1946-2008: A Chronological and Topical Outline. The Journal of Slavic Military Studies, [S.l.], v. 23, n 1, pp. 27-235, 2010.

GLANTZ, David M et al. Slaughterhouse: the handbook of the Eastern front. Bedford: The Aberjona Press, 2004.

GLANTZ, David M.; HOUSE, Jonathan M. When titans clashed: how the red army stopped Hitler, revised and expanded edition. Lawrence: University Press of Kansas, 2015.

GREENFIELD, Kent; PALMER. Robert R; WILEY, Bell I. The army ground forces: the organization of ground combat troops. Washington: Center of Military History, 1987.

GROPMAN, Alan. Introduction. In: GROPMAN, Alan (ed.). The big “L”: American logistics in World War II. Washington: GPO, 1997. p. ix-xii.

GUDMUNDSSON, Bruce I. On artillery. Westport: Praeger, 1993.

GUDMUNDSSON, Bruce I. On armor. Westport: Praeger, 2004.

GUNSTON, Bill. Modern fighting helicopters. London: Salamander, 1999.

HANSON, Philip. The rise and fall of the Soviet economy: an economic history of the USSR 1945-1991. London: Pearson Education Limited, 2003.

HAWKINS, Glen R. US army force structure and force design initiatives 19391989. Washington: US Center for Military History, 2013.

HAWKINS, Glen R.; CARAFINO, Jay. Prelude to army XXI: U.S. army division design initiatives and experiments, 1917-1995. Washington: Center of Military History, 1997.

HAYTHORNTHWAITE, Phillip J. The napoleonic sourcebook. London: Arms and Armour Press, 1997.

HERBERT, Paul H. Deciding what has to be done: General William E. DePuy and the 1976 edition of FM 100-5, operations. Fort Leavenworth: Combat Studies Institute, 1988.

HOUSE, Jonathan M. Toward combined arms warfare: a survey of 20th-Century tactics, doctrine, and organization. Honolulu: University Press of the Pacific, 2002. 
HOUSE, Jonathan M. A military history of the Cold War, 1962-1991. Norman: University of Oklahoma Press, 2020.

IISS. The International Institute for Strategic Studies. The military balance 2016 London: Routledge, 2016.

ISBY, David C. Weapons and tactics of the Soviet army. London: Jane's, 1988.

JARYMOWYCZ, Roman. Tank tactics: from Normandy to Lorraine. Mechanicsburg: Stackpole, 2008.

JORDAN, David et al. Understanding modern warfare. 2. ed. Cambridge: Cambridge University Press, 2016.

KEDZIOR, Richard W. Evolution and endurance: the U.S. army division in the 20th Century. Santa Monica: Rand Publishing, 2000.

LEIGHTON, Richard M.; COAKLEY, Robert W. Global logistics and strategy, 19401943. Washington: Office of Chief of Military History, 1955.

MCCONVILLE, James C. Army multi-domain transformation. Washington: Headquarters: Department of the Army, 2021. (Chief of Staff Paper \#1).

MACGREGOR, Douglas A. Breaking the phalanx: a new design for landpower in the 21st Century. 3. ed. Westport: Praeger, 1997.

MACGREGOR, Douglas A. Transformation under fire: revolutionizing how America fights. Westport: Praeger, 2003.

MANDELES, Mark. The future of war: organizations as weapons. Washington: Potomac Books, 2005.

MARTYANOV, Andrei. Losing military supremacy: the myopia of American strategic planning. Atlanta: Clarity, 2018.

MCGOWEN, Stanley S. Helicopters: an illustrated history of their impact. Santa Barbara: ABC-CLIO, 2005.

MILLER, Christopher F. Modern land combat. London: Salamander, 2001.

O'HANLON, Michael E. The science of War: defense budgeting, military technology, logistics, and combat outcomes. Princeton: Princeton University Press, 2009. 
OHL, John Kennedy. Supplying the troops: General Somervell and American logistics in World War II. Ithaca: Cornell University Press, 2020. E-book.

REESE, Roger R. The Soviet military experience: a history of the Soviet army, 1917-1991. London: Routledge, 2000.

RENZ, Bettina. Russia's military revival. Cambridge: Polity, 2018. E-book.

ROMJUE, John. From active defense to airland battle: Development of Army Doctrine 1973-1982. Fort Monroe: TRADOC, 1985.

ROMJUE, John. The army of excellence: the development of the 1980 s army. Ft. Monroe, VA: TRADOC, 1997.

ROTTMAN, Gordon L. Inside the US army. Oxford: Osprey, 1988.

ROTTMAN, Gordon L. World War II combat reconnaissance tactics. Oxford: Osprey, 2007.

ROTTMAN, Gordon L. World War II infantry assault tactics. Oxford: Osprey, 2008.

ROTTMAN, Gordon L. World War II US armored infantry tactics. Oxford: Osprey, 2011.

SKINNER, Michael. USAREUR: the United States army in Europe. Novato: Presidio, 1989.

STEWART, Richard W. American military history volume 2: the United States army in a global era, 1917-2010. 2. ed. Alexandria: St John's Press, 2010.

SUTYAGIN, Igor; BRONK, Justin. Russia's new ground forces. Abingdon: Routledge, 2017.

US ARMY. FM 100-5 operations. Washington: GPO, 1976.

US ARMY. FM 100-2-1 the Soviet Army, operations and tactics. Washington: GPO, 1984.

US ARMY. FM 100-2-3 the Soviet army: troops, organization and equipment. Washington: GPO, 1991.

TUCK, Christopher. Understanding land warfare. Abingdon: Routledge, 2014. 
VVAA. Soviet TO\&Es 1980-1989: v 1.9. Ocean Isle Beach: Fire and Fury Games, 2011.

WILSON, John H. Maneuver and firepower: the evolution of divisions and separate brigades. Washington: Center of Military History: US Army, 1998.

ZALOGA, Steven J. Tank war-central front. Oxford: Osprey Publishing, 1989.

ZALOGA, Steven J. US armored divisions: the European theater of operations, 1944-45. Oxford: Osprey Publishing, 2004.

ZALOGA, Steven J. US armored units in the North Africa and Italian campaigns 1942-45. Oxford: Osprey Publishing, 2006.

ZALOGA, Steven J. US field artillery of World War II. Oxford: Osprey Publishing, 2011.

ZALOGA, Steven J; NESS, Leland S. The red army handbook, 1939-1945. Stroud: Sutton Publishing, 1998. 